\title{
Absolutismo y fiscalidad en Castilla a fines del siglo XVII: el encabezamiento general del reino (1682-1685)
}

\author{
Juan A. Sánchez Belén *
}

A Joaquín Blázquez Sánchez. In memoriam

En un trabajo antiguo, todavía no superado, Domínguez Ortiz ha escrito que la aristocracia, excluida de las Cortes desde 1538 y limitada su participación en el aparato burocrático del Estado, propendió a monopolizar la vida política de los municipios, desplazando al estamento plebeyo de los oficios más relevantes ${ }^{1}$. Este proceso, que se configura con nitidez durante el reinado de Felipe II, en que se produce una fuerte reacción nobiliaria contra el ejercicio de cargos en los ayuntamientos por individuos cuyos antepasados, o ellos mismos, habian desempeñado, o desempeñaban aún, "oficios mecánicos" o "viles", parece culminar en el siglo XVil cuando la nobleza, después de acaparar los puestos más cotizados de la administración de las ciudades y villas - no sin resistencia del estamento llano, quien, por otro lado, nunca quedó relegado por completo de representatividad en los municipios, aunque los efectos que

* Profesor titular de la UNED.

1 A. Domínguez Ortiz, La sociedad española en el siglo xvit. Madrid 1963, t. I, p. 25357 y Las clases privilegiadas en el Antiguo Régimen. Madrid 1979, p. 121 y ss. Este Jibro resume lo estudiado en el anterior, aunque suprime algunos capítulos, como el relativo a la demografía castellana del siglo XVII. Si aquí lo mencionamos es por su mayor asequibilidad para el lector. Abunda en el tema J. BENEYTO. Historia de la administración española e hispanoamericana. Madrid 1958, p. 383. 
hubieran podido derivarse de su presencia fueron de inmediato contrarrestados por su tendencia al ennoblecimiento ${ }^{2}$ - consigue recuperar su hegemonía en las Cortes gracias a las procuraciones que regenta e insertarse en el gobierno de la Monarquía, llegando a imponer su peculiar criterio de élite - también sus intereses económicos- a los soberanos, lo cual, según José Antonio Maravall, no implicó ningún deterioro del absolutismo de los Habsburgo, sino, más bien, lo contrario, su fortalecimiento ${ }^{3}$.

2 B. GonzAlez Alonso, "Sociedad urbana y gobierno municipal en Castilla (14501600)", Sobre el Estado y la administración de la Corona de Castilla en el Antiguo Régimen. Madrid 1981, p. 57-83.

Domínguez Ortiz, por su parte nos advierte sobre lo inexacto que es asegurar que Felipe II desdeñó a la nobleza y la apartó de los cargos burocráticos, pues lo que hizo fue "preferir a la nobleza media e inferior por desconfianza hacia los grandes señores" (La sociedad española..., p. 270 y Las clases privilegiadas..., p. 124). Que la nobleza no consiguió imponerse de manera absoluta en los municipios castellanos nos deja constancia de ello Domínguez Ortiz al establecer una variada tipología de sistemas de gobierno en los ayuntamientos (La sociedad española..., p. 255 y Las clases privilegiadas..., p. 124). Por otro lado, la insistencia del estamento llano para que se nombren procuradores del común y los obstáculos que encontró en aquellas localidades donde la aristocracia era potente, inciden en lo que llevamos dicho. Sobre este aspecto escasamente estudiado se puede consultar la comunicación presentada en el I Congreso de Historia de Castilla-La Mancha por Ana GuerRero MayLlo, bajo el título «La representación popular en los concejos castellanos: el procurador del común en La Mancha durante el siglo XVI"». Ciudad Real 1988, t. VII, p. 29-35.

3 J. A. Maravall, Poder, honor y élites en el siglo xvil. Madrid 1978.

Acerca de la preponderancia de la nobleza local en las Cortes castellanas, J. BENEYTO, obra citada, p. 361; A. Dominguez ORTIz, La sociedad española..., p. 271 y Las clases privilegiadas..., p. 125. En cuanto a la presión ejercida por las Cortes en las decisiones de la Corona, el planteamiento tradicional expuesto por M. DANVILA y COLLADO de que desde Villalar dejaron de desempeñar un papel activo en el control del absolutismo monárquico (ver "Cortes de Castilla de 1576», Boletín de la Real Academia de la Historia, VII, 1985, p. 312-335 y El poder civil en España. Madrid 1889), idea que retoma J. I. GutiérRez Nieto ("El sistema fiscal de la Monarquía de Felipe IV». Historia de España Menéndez Pidal, Madrid 1982, t. XXV, p. 257-332), está siendo revisado en la actualidad por Charles JAGO ("Habsburg Absolutism and the Cortes of Castile», The American Historical Review, 86, $\mathrm{n}$. 2, 1981, p. 307-326 y «Philip II and the Cortes of Castile: The case of the Cortes of 1756", Past and Present, n. ${ }^{109}, 1985$, p. 24-43, asi como por I. A. A. THOMPSON, "Crown and Cortes in Castile, 1590-1665", Parliamente, Estates and Representation, n. ${ }^{\circ}$ 2, 1982, p. 29-45.

Por lo que se refiere al predominio de la aristocracia en los Consejos, A. Dominguez Ortiz, La sociedad española... I, p. 270-271 y Las clases privilegiadas..., p. 141. Ahora bien, si es cierto que muchos pertenecian a la nobleza media -en el Consejo de Estado primaban, en cambio, los grandes títulos---, el citado historiador no nos especifica si procedían o no de familias vinculadas a la administración municipal. Esta laguna la cubre en parte J. FAYARD (Les membres du Conseil de Castille a l'époque moderne [1621-1746]. París, 1979) cuando resalta que un nutrido grupo de ministros de dicha institución estaba emparentado con familias que habian ejercido cargos públicos en los ayuntamientos. $Y$ es lógico pensar que lo propio sucedería en el resto de los Consejos, aunque todavía están por estudiar total o parcialmente. 
No obstante, en las décadas últimas del siglo XVII aparecen signos inequícovos de una cierta disensión entre el Estado y las aristocracias ciudadanas. Los factores que explican este cambio -es muy significativo, por lo que se refiere a las ciudades, la repulsa de Carlos II y sus ministros a convocar Cortes generales en Castilla, como lo habían practicado sus antecesores- son confusos todavía, a no ser que se haya ido gestando un relevo, soterrado y lento pero firme, en las élites de los municipios que amenaza a la vieja aristocracia establecida en el poder, o, lo que es asimismo probable, que en los órganos centrales del gobierno, preferentemente en los Consejos de Castilla y de Hacienda, comienzan a primar nuevos grupos económicos, tal vez de idéntica procedencia social que los anteriores o, cuando menos, ennoblecidos, pero, en cualquier caso, con formación e intereses distintos -es muy sospechoso el afán del duque de Medinaceli y de don José de Veitia y Linaje por el fomento de la industria y del comercio, no demasiado justificado por su apego a los modelos proteccionistas de Inglaterra, Holanda, Francia e incluso Portugal-, en abierta ruptura con aquellos que aún ejercen su influencia en la esfera municipal y obstaculizan el ascenso a individuos más dinámicos que persiguen sustituirles en sus funciones rectoras y en sus preeminencias. Sean cuales fueren las causas -nos queda mucho por conocer sobre el gobierno de los municipios y las familias que lo regentaron, así como de la composición de los Consejos-, lo evidente es que desde Madrid algunos ministros tratan de moderar la autoridad e independencia de los ayuntamientos $-\mathrm{y}$, por tanto, de los grupos oligárquicos en ellos representados- en aquellas materias que son competencia exclusiva del Estado, según la doctrina de la época: el ordenamiento económico y fiscal del Reino ${ }^{4}$. No creemos aventurado afirmar entonces que estamos ante una nueva fase de la construcción del Estado moderno, iniciada, es verdad, con anterioridad - a modo de ejemplo se puede recordar el programa del Conde-duque de Olivares o la incorporación del servicio de millones, administrado por las ciudades con voto en Cortes, al Consejo de Hacienda desde $1658^{5}$ - pero que en

4 «La economía se convierte -nos dice MARAVALL - en todas partes en un sector de la vida social que el Estado atrae a su órbita, cualquiera que fuesen los resultados finales. $Y$ hay que ver en esto un aspecto que caracteriza la figura del Estado moderno" (ver Estado Moderno y mentalidad social. Madrid 1974, t. II, p. 295).

El 4 de marzo de 1647 un Real Decreto incorpora al Consejo de Hacienda la Junta de Millones a raíz de un altercado protagonizado por el conde de Lemos, que pretendía no sólo ser elegido miembro de la citada Junta sin entrar en el sorteo que en cada legislatura se realizaba para el nombramiento de los procuradores que deberían integrarla, sino también que la presidencia recayera en su persona por ser Grande de España, lo cual vulneraba las condiciones estatutarias que reglamentaban correspondía al presidente del Consejo 
las postrimerías del siglo XVII alcanza un desarrollo notable, sin el cual no se puede comprender - al menos no del todo - el Despotismo llustrado de los Borbones: aludimos a la etapa definida por José Antonio Maravall, en la que el poder absoluto "es capaz de actuar, en virtud de su exención jurídica, sobre el derecho patrimonial, de operar sobre la estructura social misma y de reconstruirla según su voluntad" ${ }^{6}$.

Las varias reformas emprendidas en Castilla desde 1669 en el sistema recaudatorio y administrativo de los impuestos, con el propósito de mejorar la rentabilidad de los ingresos fiscales y de aliviar a los vasallos de contribuciones o, cuando menos, de procurar que su exacción no fuese tan gravosa, nos vienen a confirmar que la Corona estaba resuelta a mantener sus criterios a expensas de los defendidos por unas autoridades municipales que, en el sentir del Consejo de Hacienda, sólo perseguían su máximo provecho en detrimento del Estado y de los contribuyentes. Será, sin embargo, en 1682 cuando el gobierno aborde con firmeza un cambio trascendental en su anquilosado sistema tributario - anticipemos que la experiencia estuvo en vigor unícamente durante un trienio-, según venían solicitándole los arbitristas ante los perjuicios que ocasionaba a los lugares el mantenerse, sin apenas control de la Corona, los arrendamientos o la administración por las ciudades y villas encabezadas de las rentas provinciales, es decir, de las alcabalas, cientos, millones y servicio ordinario y extraordinario ${ }^{7}$, lo cual, por otro lado,

de Hacienda. Este suceso, que en apariencia venía motivado por una desusada ansia de poder, tal vez, sin embargo, fuese una mera provocación prevista por la Corona para asi limitar la autonomía que las ciudades con voto en Cortes gozaban en la administración del servicio (ver Memorial Histórico Español, XVIII, p. 371). No obstante, el 9 de marzo de 1649 la Junta de Millones recuperó su independencia hasta su unión definitiva con el Consejo de Hacienda por Real Cédula de 30 de mayo de 1658 (Novísima Recopilación, ley V, tít. X, lib. VI). Según Barrionuevo, el decreto de disolución e incorporación llevaba fecha de 11 de abril de 1658 (Avisos. Madrid 1959, II, p. 214). Sobre este asunto se puede consultar J. DE RiPIA, Práctica y administración de las rentas reales.... Madrid 1676, p. 190-193; F. Gallardo Fernández, Origen, progresos y estado de las rentas de la Corona de España, su gobierno y administración. Madrid 1805, I, p. 61-66; M. ARTOLA, La Hacienda del Antiguo Régimen. Madrid 1982, p. 137-138; T. Garcia-Cuenca ARIATI, «El Consejo de Hacienda (1476-1803)", La Economía española al final del Antiguo Régimen. IV. Instituciones. Madrid 1982 , p. 447-448.

J. A. Maravall, Estado Moderno y mentalidad social, t. 1, p. 299.

7 Asentistas y arrendadores, escribe SOMOZA y QUIROGA, «discurren siempre hacia el lado de sus grandes intereses" (Unico desengaño y perfecto remedio de los menoscabos de la Corona de Castilla y general alivio de todos sus vasallos..., 1680, editado por VALLADARES DE SOTOMAYOR en Semanario Erudito, Madrid 1787, vol. IX, p. 225-256), idea que ya había expresado un año antes Gavı y CATANEo (Tratado en orden a una general reforma de millones, asi para el mayor servicio de S. M. como para universal alivio de los vasallos..., 
contradice la opinión sustentada por J. H. Elliott de que el fracesso del programa del Conde-duque de Olivares paralizó todo activismo político por parte del gobierno central hasta la llegada de los Borbones ${ }^{7 \text { bis. }}$.

\section{EL ENCABEZAMIENTO GENERAL DEL REINO Y LA INSTRUCCIÓN DE 1682}

El punto de partida de esta reforma tendrá lugar al mes escaso de producirse el reajuste monetario de 1680 y sus protagonistas serán don Luis Moreno Ponce de León y don Juan de la Hoz Mota, del Consejo de Hacienda, quienes, el 25 de marzo de dicho año, plantean la conveniencia de que el Estado administre las rentas provinciales previo encabezamiento de los pueblos, a cuyo intento se desplazarán ministros de solvencia probada para que averiguen las cantidades abonadas en el quinquenio último $\mathrm{y}$, conforme a sus valores, ajusten lo que deberán contribuir en adelante. El objetivo que pretendían era doble: de un lado, subsanar las deficiencias observadas en la concesión de los arriendos, toda vez que los arrendatarios concertaban con la Real Hacienda el disfrute de las rentas por un importe muy inferior al que luego repartian entre los contribuyentes; de otro, aliviar a los súbditos de la presencia de ejecutores, cuyos salarios y costas suponían gravámenes adicionales a los impuestos, tal como se desprende de los numerosos memoriales remitidos durante estos años al Consejo de Hacienda ${ }^{8}$.

Granada 1679 y 1681) y que ÁlvaREZ Osorıo vuelve a plantear cuando denuncia la formación de conciertos o "trust» entre asentistas y arrendadores para que en las pujas de las rentas o de los préstamos nadie ofrezca precios más altos ni mejores condiciones a fin de obtener como mínimo el cien por cien de ganancias (Zelador General para el bien común de estos Reinos..., BNM, Mss. 6659). En cuanto a la crítica del sistema recaudatorio, especialmente de las audiencias y ejecutores, además de las expuestas en los escritos mencionados, se puede recordar las formuladas por Francisco CEnTani (Tierras: Medios universales propuestos..., BNM, VE, 69/54) y PORTOCARRERo (Theatro Monárquico de Es. paña que contiene las más puras como cathólicas máximas de Estado.... Madrid 1700).

7 bis J. H. ELLIOTT, «Poder y propaganda en la España de Felipe IV", Homenaje a J. A.

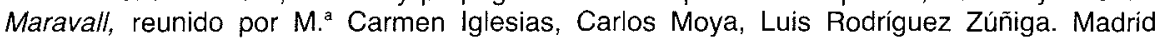
1985 , t. I, p. 42.

8 Archivo General de Simancas (AGS), Consejo y Juntas de Hacienda (CJH), Leg. 1404. Consulta de 25 de marzo de 1680. Las peticiones de los pueblos se pueden localizar en los legajos 1407-08, 1410 y 1411. 
El proyecto, sugerido ya en 1669 y desestimado por el entonces presidente de Hacienda, don Lope de los Ríos ${ }^{9}$, es examinado el siete de abril y rechazado por la mayoría de los consejeros, mas, como se argumenta, "por la dificultad de su ejecución que por la substancia» ${ }^{10}$. Poco tiempo después de esta consulta desfavorable, el Consejo de Castilla, situado ante la disyuntiva de pronunciarse entre los problemas inmediatos que se derivarían de su aplicación (retrasos en las cobranzas de los impuestos y en el pago de juros y libranzas, con el seguro retraimiento de los asentistas a conceder préstamos) y su utilidad a medio - largo plazo, tanto para los súbditos como para los ingresos del erario, optará porque se implante, a modo de ensayo, en algunas provincias, tales que Burgos y León ${ }^{11}$.

A pesar de las objeciones formuladas, el 12 de octubre de 1681 la Corona acepta la iniciativa propuesta, si bien los brotes epidémicos acaecidos en Córdoba y en La Puebla de Alcocer (Badajoz) en la primavera de 1682 aconsejan demorar su ejecución, como así sucede, hasta el 16 de diciembre, fecha en la que una Cédula Real decreta, por fin, el ansiado encabezamiento general del Reino, a la par que establece $-\mathrm{y}$ esto es importante retenerlo- superintendencias en las veintiuna provincias de Castilla, a quienes se somete no sólo la averiguación de las cantidades adeudadas y repartidas a los pueblos, su vecindad, riqueza, tratos y comercio para acomodar los impuestos a las posibilidades económicas de los habitantes, sin permitir que los poderosos queden exentos y damnificados los humildes, sino también la administración de las rentas en sus respectivas demarcaciones. Junto a esto se abroga el sistema de los arriendos - la Cédula que lo confirma está fechada el 12 de enero de $1683^{12}$ - y se constituye una Junta especial, denominada de Encabezamientos, encargada de supervisar las gestiones de los superintendentes y demás funcionarios que les acompañan, con jurisdicción privativa sobre cualquier otro tribunal, ya sea civil o eclesiástico, para lo cual los Consejos de Castilla, Guerra, Inquisición y Órdenes expedirán los oportunos despachos inhibiendo a sus ministros de toda acción que obstaculice las pesquisas y ajustes realizados por los funcionarios de las superin-

9 Biblioteca Nacional de Madrid (BNM), Mss. 19800/6, fol. 303.

10 AGS, CJH, Leg. 1410. Consulta del Consejo, 7 de abril de 1680; Archivo Histórico Nacional (AHN), Consejos Suprimidos (Conss), Leg. 7191, exp. 4. Quien aprueba el proyecto, además de sus promotores, fue don Luis de Haro.

AHN, Conss, Leg. 7191, exp. 4. Consulta del Consejo de Castilla, 6 de agosto de 1681.

12 AGS, Dirección General del Tesoro (DGT), Inventario 24, Leg. 647, exp. 128. 
tendencias ${ }^{13}$. Por último, la Junta, presidida por el duque de Medinaceli e integrada por dos consejeros de Castilla, otros dos de Hacienda, un procurador de Cortes de la Sala de Millones y un secretario ${ }^{14}$, elabora unas Instrucciones muy precisas de lo que deberán observar los superintendentes en el desempeño de sus comisiones -la asignación de los cargos se promulga el 17 de diciembre de $1682^{15}$ - y que resumen con toda exactitud lo que el Estado perseguía realizar con esta reforma, muy en la línea, por otro lado, del modelo administrativo francés, tal como se contiene en un informe enviado a comienzos del reinado por el que era embajador en París, marqués de La Fuente ${ }^{16}$.

Tres cuestiones esenciales cabe destacar en la Instrucción de 1682. En primer lugar, el procedimiento tradicional de arrendar, encabezar o administrar por el Consejo de Hacienda las rentas provinciales, cuando

13 British Library, Eggenton (Egg), Leg. 339, fol. 510v-511. Real Cédula de 16 de diciembre de 1682. La decisión aparecia ya insertada en la consulta del Consejo de $\mathrm{Ha}-$ cienda de 9 de noviembre de 1680 (AGS, CJH, Leg. 1410).

14 Estos ministros fueron, respectivamente, don Gil de Castejón, don Carlos de Villamayor, el conde de Humanes, a la sazón gobernador del Consejo de Hacienda, don Luis Moreno Ponce de León y don Diego de Cetina -éste por la Sala de Millones-. El cargo de secretario recayó en don Juan Ignacio Bautista de Rivas.

${ }_{15}$ La relación de superintendentes, los cargos que ocupaban y los lugares de sus destinos, es la siguiente: Ávila, don Pedro Núñez de Prado, corregidor; Burgos, don Diego de Alvarado, del Consejo de Indias; Córdoba, don Francisco Ronquillo, su corregidor; Cuenca, don Fermín de Marichalar, del Consejo de Castilla desde 1682; Extremadura, don Luis Moreno Pacheco, administrador general de las rentas de Córdoba; Galicia, don Juan de Feloaga, del Consejo de Hacienda; Granada, don Juan de la Hoz Mota, del Consejo de Hacienda; Guadalajara, don Francisco de Guadalfajara, del Consejo de Hacienda; Jaén, don Leonardo de la Cueva Cepero, alcalde de gradas de la Real Audiencia de Sevilla; León, don Pedro de la Puente, su corregidor; Madrid, don Luis Moreno Ponce de León, del Consejo de Hacienda; Murcia, don Luis Salcedo, del Consejo de Castilla; Palencia, don Pablo de Guzmán, de la Contaduría Mayor de Cuentas; Salamanca, don José Francisco de Aguirre y Álava, del Consejo de Hacienda; Segovia, don Alonso Guillén de la Carrera, del Consejo de Castilla desde 1682; Sevilla, don Julián de Cañas, oidor del Consejo de Hacienda; Soria, don Pedro Velluti de Haro, corregidor de Logroño; Toledo, marqués de Ugena, del Consejo de Hacienda; Toro, don Antonio de la Oca Sarmiento, diputado del Reino de Galicia y ministro de la Sala de Millones; Valladolid, don Pedro de Oreitia, del Consejo de Hacienda; Zamora, don Rodrigo Godinez, su corregidor.

Hay que señalar que algunos fueron sustituidos en el transcurso de 1683, como sucede con don Juan de Feloaga y don Luis Salcedo; el primero por el conde de Uceda, gobernador del Reino; el segundo, por don Francisco Miguel de Pueyo, corregidor de Murcia. La información está localizada en British Library, Egg, Leg. 339, fol. 510-511 y Add, Leg. 9935, fol. 468-69. Ciertos datos los he completado con el libro ya citado de J. FAYARD.

${ }_{16}$ AGS, $C J H$, Leg. 1966. Instrucción de lo que han de observar los ministros que han de salir a los encabezamientos de las rentas reales y servicios de millones de todas las ciudades, villas y lugares del Reino, divididos por provincias, ajustamiento de cuentas de los débitos hasta el fin de este año, y su cobranza, 1982. 
no se hallaban arrendatarios o no se avenían los pueblos a encabezarse, desaparece y es sustituido por un encabezamiento general del Reino, asignándose a los superintendentes, auxiliados por un contador, un escribano y un alguacil, elegidos entre los más expertos de los distintos organismos del Estado, su administración, estando facultados para despachar ejecutores, jueces y audiencias contra las localidades deudoras o remisas al pago de los tributos y para subdelegar sus funciones en cada partido a los corregidores o cualesquiera individuos que consideren capacitados, los cuales, sujetos a su autoridad, mantendrán una correspondencia fluida acerca de sus gestiones ${ }^{17}$. Con este sistema no sólo se racionaliza y simplifica el gobierno de las rentas provinciales, sino que, además, se centraliza y, en el caso del servicio de millones, se limita la autonomía de las ciudades con voto en Cortes, pues el impuesto escapa de su control e incluso del de la Sala de Millones, que recordémoslo, está compuesta desde 1658 por el presidente de Hacienda y cuatro procuradores de Cortes. También se agiliza la disponibilidad financiera de los tributos referidos al establecerse que los superintendentes y administradores, tras detraer en concepto de salario un tanto por ciento de lo que en persona hubiesen recaudado, destinarán el remanente de lo ingresado en las arcas provinciales o en las tesorerías de los partidos - a las primeras se conduce lo procedido del servicio de millones; a las segundas el de las alcabalas, cientos, papel sellado y servicio real- al pago de libranzas despachadas por el Consejo de Hacienda y la Sala de Millones ${ }^{18}$. En ningún caso $-y$ sobre este particular se aconseja dediquen especial cuidado los superintendentes-, los contadores y escribanos podrán percibir remuneración alguna por los autos, ajustes de cuentas, certificaciones o despachos que expidieren, ni los ministros subalternos regalos, dinero o alimentos, advirtiéndoseles que los infractores perderán sus oficios y serán sancionados por la Junta en la forma que juzgare adecuada ${ }^{19}$. Por su parte, los ayuntamientos deberán nombrar en sus localidades a los arqueros, tesoreros y depositarios, señalándoles un salario digno, con la condición expresa de que los empleos no recaigan en regidores ni escribanos «por los inconvenientes que han resultado y resultan de lo contrario" ${ }^{20}$.

El segundo aspecto previsto en la Instrucción trata de acomodar los

17 Ibidem, artículo 4.

18 Ibidem, artículo 15. El salario de los superintendentes se evalua en un dos por ciento de lo recaudado y el de los administradores en un medio por ciento.

19 Ibidem, artículo 29.

20 Ibidem, artículo 25. 
tributos de los lugares a su vecindad y recursos económicos, lo que no se hacía con carácter general desde el censo de 1590/91, a cuyo fin se ordena a los superintendentes que confeccionen padrones de vecindad, resaltando las actividades productivas y si son o no consumidores de lo que producen ${ }^{21}$. En virtud de estos datos se ajustará el encabezamiento, suscribiendo las localidades una escritura por alcabalas y cientos y otra por millones que garantizarán sus justicias y contra las que se despacharán ejecutores y audiencias de no abonar el importe estipulado ${ }^{22}$. Si algunas villas o ciudades no aceptasen el encabezamiento propuesto quedarán en administración con los valores estimados por el superintendente o con los que tenían antes, encargándose de su cobranza las justicias, quienes, bajo su responsabilidad, elegirán un fiel receptor al que entregarán lo recaudado, para que éste, a su vez, lo remita a la tesorería de su partido ${ }^{23}$. Como la medida debe favorecer a todos los súbditos, se advierte a los superintendentes que negocien con los propietarios de rentas provinciales enajenadas la posibilidad de reducir lo que perciben en una suma proporcional a la que concede la Corona, cuando así se desprenda de las necesidades de los lugares, pues sus vecinos son tan vasallos del rey como los demás "y no será justo que la comodidad que se les hiciere en lo que a mi me contribuyen, con baja y menoscabo de mis rentas, ceda en aumento de lo que pagan a los que las tienen por venta, habiendo salido de mi Real Patrimonio» ${ }^{24}$.

Asimismo se regula el procedimiento que ha de observarse en la cobranza y ajuste de los débitos. A este efecto, los superintendentes, provistos de relaciones pormenorizadas de los valores de las rentas y de lo ingresado en las arcas o en las tesorerías, indagarán los motivos que justifican el endeudamiento. Si éste tuviese su origen en «la falta de frutos o de salud general en el lugar o por alguna tempestad de piedra e inundación o por otra causa o accidente muy grave, y que el lugar está tan pobre que le sea imposible el pagar lo que debe» ${ }^{25}$, entonces se podrá perdonar a los contribuyentes alguna cantidad, previa aceptación de la Junta, fijándose los plazos y condiciones de pago más en consonancia con sus posibilidades, así como los arbitrios que les permitan

21 Ibidem, artículo 18. «Hareis numeración de los vecinos de cada lugar, declarando los exentos y reconocereis los tratos, labores y granjerias que tienen, si es lugar de frutos o de sólo consumo, y de todo se ha de formar relación con entera claridad".

22 Ibidem, artículo 18.

23 Ibidem, artículo 19.

24 Ibidem, artículo 26.

25 Ibidem, artículo 9 . 
allegar recursos para su satisfacción, exceptuadas las sisas sobre el vino, vinagre, aceite y carne ${ }^{26}$. Esta disposición, que será también válida en los casos en que el producto de los impuestos se hubiese visto afectado por devaluaciones monetarias o se hubiese empleado en el alojamiento de tropas, repartos de camas, cebada para las caballerías o cualesquiera otros efectos autorizados por el Consejo de Hacienda -dichas sumas se considerarán recaudadas y se descontarán del monto de los débitos, siempre que no se hubieran satisfecho por la Corona ${ }^{27}$, no se observará cuando la deuda proceda de la omisión o negligencia de las justicias o cuando los fieles, receptores y alcaldes mayores hayan usurpado las rentas o destinado su importe en gastos del concejo - en estos casos se prevé que el monto del alcance se cobrará de sus bienes ${ }^{28}-$. El débito resultante, deducidas las bonificaciones mencionadas y que irán especificadas sobre qué rentas y en qué años se consignan, para que se puedan despachar los oportunos libramientos a los juristas y demás interesados, quedará escriturada, comprometiéndose las justicias con sus haciendas a ingresar el dinero en las arcas o tesorerías donde los contadores dispondrán de una copia de la escritura a fin de controlar cómo se va cancelando ${ }^{29}$. Por último, se prescribe que los superintendentes procedan a tantear con los tesoreros, receptores, arqueros y depositarios las sumas percibidas de los contribuyentes y los desembolsos autorizados por el Consejo de Hacienda o la Sala de Millones, exigiéndoles la entrega de los caudales que tuvieren en su poder ${ }^{30}$, a la vez que se decreta una suspensión temporal de pagos a los arrendatarios mientras no se determinen las cantidades que la Corona les adeuda por sus anticipaciones y los valores que están obligados a ingresar del tiempo de sus arrendamientos ${ }^{31}$.

No hay duda que estas prevenciones permiten a los contribuyentes mejorar su nivel de vida y disponer de recursos financieros susceptibles de acelerar la productividad mediante el consumo o la inversión. Para afianzar este objetivo, el Estado - y con ello entramos en el tercer aspecto prevenido en la Instrucción- elaborará una normativa dirigida al fomento de la economía, sobre todo de la industria -el desarrollo agrícola parece quedar postergado, salvo si se trata de cultivos con fines

\footnotetext{
Ibidem, artículos 9 y 10.

Ibidem, artículo 8.

Ibidem, artículo 10

Ibidem, artículos 9 y 11.

Ibidem, artículo 12.

Ibidem, artículo 17.
} 
industriales, como el tabaco, la caña de azúcar, la morera, el lino y el cañamo ${ }^{32}-y$, algo más distanciada, de la ganadería. Esto se configura con nitidez, no ya en la orden dada a los superintendentes para que procuren aplicar los medios más adecuados a la conservación y restablecimiento de aquellas manufacturas que en el pasado y en el presente fueron y siguen siendo el sustento de numerosas familias y uno de los fundamentos de su progreso ${ }^{33}$, sino también en la suspensión de determinados tributos, estatales o municipales, que afectan a los artículos de primera necesidad: de un lado, los millones aprobados por el Reino en $1656 / 57$, cuya cuantía queda subsumida en el ajuste que se realice del servicio y de las milicias ${ }^{34}$; de otro, las sisas impuestas por los ayuntamientos, si bien en tanto no se establezcan arbitrios sustitutivos se mantendrán para no damnificar a los censualistas, aunque éstos no percibirán por sus intereses más del 5 por 100 , según lo estipulado en $1669^{35}$. Asimismo se prorroga a los concejos el aprovechamiento o enajenación de los pastos comunales o talas de bosques para el pago de los impuestos, pero siempre que ello no suponga ningún perjuicio económico para los vecinos, pues entonces el beneficio de su explotación revertirá en el común del pueblo ${ }^{36}$.

32 Es interesante constatar cómo la preocupación de los arbitristas del reinado hacia la agricultura decae considerablemente, mientras se propician los cultivos industriales, en lo que, sin duda, debemos ver el impacto del pensamiento mercantilista y también los éxitos alcanzados en este terreno por Portugal, inspirados, desde luego, en la experiencia de Colbert (Victoria RAU, «Política Económica e Mercantilismo na correspondencia de Duarte Ribeiro de Macedo (1668-1676)", Estudios de História Social y Económica do Antiguo Regime. Lisboa 1984, p. 229-267. En cuanto a la influencia de la política económica portuguesa en la literatura arbitrista castellana, ver la comunicación de Juan Carlos C. ZAPATER, «El modelo político portugués de la Restauración en el pensamiento arbitrista castellano de fines del siglo XVII", presentada en las / Jornadas de Historia Moderna celebradas en la Universidad de Lisboa los días 16-19 de octubre de 1986). De todos los arbitristas de la época quien más atención dedica al tema es Miguel Álvarez Osorio, proponiendo el cultivo del lino y semillas industriales en las vegas del Henares, Jarama y Tajo, así como en Galicia y La Alcarria (Zelador General..., p. 9-10 y 14).

33 lbidem, artículo 22.

34 lbidem, artículo 24.

35 Ibidem, artículo 20. La reducción del tipo de interés de los censos redimibles al $5 \%$ data de 1608, aunque los demás préstamos tienen más crecidos intereses. El 7 de octubre de 1621, Felipe IV confirma dicha reducción aplicándose ahora tanto a los que se contratan como a los existentes aunque estuviesen suscritos a mayor precio. El 27 de julio de 1632 una Cédula Real ratifica la pragmática anterior (Leyes XII y XIII, tít. XV, lib. V de la Nueva Recopilación, si bien no parece que se observara, puesto que se vuelve a promulgar en 1669 a raíz de una consulta de la Junta de Alivios de 15 de abril (BNM, Mss. 19700/6, fol. $283 \mathrm{~V}$ y 291-93V) y se recuerda nuevamente en la Instrucción de 1682.

${ }_{36}$ Ibidem, artículo 21. La concesión de arbitrios para la paga de impuestos, y muy especialmente del servicio real, adquiere un gran interés entre los ministros de los Consejos de Castilla y de Hacienda, como se deduce del artículo 13 de la citada Instrucción, en que 
El proyecto de la Junta de Encabezamientos transciende, por tanto, el contenido inicial del plan presentado en 1680 por don Luis Moreno Ponce de León y don Juan de la Hoz Mota. Ahora, además de reformar el sistema administrativo de las rentas provinciales, suspendiendo los arriendos, se procura ajustar las cuentas con los arrendatarios y con quienes, de una u otra forma, administran los caudales del erario, a la vez que se promueve el alivio fiscal de los súbditos, moderando en una cierta suma su endeudamiento y adaptando las cargas tributarias a la vecindad de los lugares y a lo que pueden contribuir, ya que de otro modo, según el parecer de la época, ni ellos ni el Estado podrán afrontar con éxito la difícil coyuntura económica que se padece ni asentar jamás los pilares que permitan el resurgir demográfico de los pueblos y la reactivación de sus actividades productivas. ¿Comprendieron los castellanos el esfuerzo enorme que la Corona estaba dispuesta a realizar en su beneficio?

\section{LA OPOSICIÓN DE LAS JUSTICIAS LOCALES A LOS ENCABEZAMIENTOS}

Cuando en los primeros meses de 1683 inician los superintendentes sus comisiones, las circunstancias demográficas y económicas del Reino distaban mucho de ser alentadoras. Las malas cosechas del sexenio $1677 / 82$, con su inevitable incidencia en el desarrollo de enfermedades epidémicas, como la peste y el tifus, muy activas durante estos años en Andalucía, Extremadura, Murcia y Castilla la Nueva ${ }^{37}$, y el hundimiento

se recomienda a los superintendentes procuren que los pueblos se repartan y no recurran a pedir arbitrios, pues casi siempre su rédito resulta deficitario y se acumulan las deudas con el erario.

37 Sobre el tema es imprescindibie la consulta del ya clásico estudio de A. Dominguez ORTIz «La crisis de Castilla en 1677-1687», Crisis y decadencia en la España de los Austrias. Barcelona 1969 , p. 195-217, asi como los trabajos de H. KAMEN, «The decline of Castilla: The last crisis", Economic History Review, 2. " serie, XVII, 1964-65, p. 63-76 y La España de Carlos II. Barcelona 1981, p. 74-97 y 150-160.

Estudios más recientes coinciden en señalar los años 1677/82 como los más penosos de finales del siglo XVII —también lo será el período 1683/85 y el año 1699-. En este sentido son muy significativos los gráficos elaborados por Vicente PÉREz MOREDA (Las crisis de mortalidad de la España interior (siglos XVI-xIX). Madrid, 1980) de Navalcarnero y Torrelaguna, en Madrid; de Mocejón, en Toledo; de Barajas de Melo, en Cuenca; de Cereceda, Chiloeches y Martel, en Guadalajara; y de Almazán y Burgo de Osma, en Soria. Por su 
del comercio interior, derivado, en parte, de los cordones sanitarios establecidos por las ciudades y villas, pero, sobre todo, del descenso de los precios y la escasez de moneda tras la devaluación de 1680, habían sumido en la pobreza a numerosas localidades, no obstante la iniciativa de don Juan José de Austria, proseguida a su muerte por el duque de Medinaceli, de otorgar a los pueblos más afectados rebajas en sus encabezamientos y deudas. Este panorama influirá de manera decisiva en

parte, Jerónimo LOPEZ-SALAZAR ( LLa población manchega en los siglos XVI y XVI!», Revista Internacional de Sociologia, Madrid, XXXIX, ${ }^{\circ}{ }^{\circ} 37$ y 38,1981 , p. 7-31 y 191-231) constata el mismo fenómeno en Almagro (parroquias de San Bartolomé y Madre de Dios), Herencia, Quintanar de la Orden, Villanueva de los Infantes y, de manera más notable, en Valdepeñas. En Sevilla, la parroquia de Santa Ana experimenta, dentro de la tendencia general de recuperación económica iniciada en torno a 1650/60, un bache pronunciado entre 1675/80, lo mismo que las parroquias de la Magdalena, el Sagrario y San Martín, mientras que en Santa María la Blanca y en San Nicolás las curvas de defunciones son superiores a los bautismos entre 1680 y 1685, al igual que en Estepa y en Tocina (ver León Carlos Álvarez SANTALO y colaboradores, "La población de Sevilla en las series parroquiales: siglos XVIXIX», Actas /I Coloquios Historia de Andalucía. Andalucía Moderna, Córdoba, noviembre 1980 , t. I, p. 19 y G. García-BAQUero LóPEZ, Estudio demográfico de la parroquia de San Martín de Sevilla (1551-1749). Sevilla 1982). Los años $1678 / 79$ y 1683/1685 son también cruciales para el desarrollo demográfico de Córdoba (J. Ballesteros Rodríguez, La peste en Córdoba. Córdoba 1982; J. I. ForTEA PÉREZ, «La evolución demográfica de Córdoba en los siglos XVI y XVII», Actas I Congreso de Historia de Andalucía, Córdoba 1978, p. 371-396; B. GARCIA JIMENEZ, "Fuentes para el estudio de la historia demográfica de una villa cordobesa en el Antiguo Régimen: el caso de Rute. Primeros resultados", Actas // Coloquios de Historia de Andalucía, t. I, p. 67-81; y B. VALle BUENESTADO, "Notas sobre la evolución demográfica en la comarca de Pedroches: 1530-1857", Actas / Congreso de Historia de Andalucía, t. II, p. 289-307), Extremadura (ver F. CORTÉs CORTÉs, La población de Zafra en los siglos XVI y XVII. Badajoz 1983, y Alfonso Rodríguez Grajera, La población de Mérida en el siglo XVII. Badajoz 1985), Granada (J. M. RABASCO VALDEZ, "Un caso de explicación de los registros parroquiales: Granada y la epidemia, 1640-1700", Actas de las I Jornadas de Metodología Aplicada a las Ciencias Históricas, Santiago de Compostela 1975, III, p. 297-308) y Jaén (L. CORONAS TEJADA, “Estudio demográfico en la ciudad de Jaén en el siglo xvII", Actas I Congreso de Historia de Andalucia..., t. I, p. 215-232). En Castilla la Vieja también aparecen indicios de la crisis referida, aunque ésta no parece ser tan grave como en otras regiones. En Segovia, La Losa y Prádena conocen años especialmente malos entre 1680/1685; Carbonero el Mayor, entre 1675/80; y Fuente el Cesped en 1680 (ver Angel García Sanz, Desarrollo y crisis del Antiguo Régimen en Castilla la Vieja. Economía y sociedad en tierras de Segovia, 1500-1814. Madrid 1977). Lo propio ocurre en Valladolid (ver los trabajos de A. GUTIÉRREZ ALONSO, "Evolución de la demografía vallisoletana durante el siglo XVI|», Investigaciones Históricas, 2, 1980, p. 37-69 y A. MARcos Martín, Auge y declive de un núcleo mercantil y financiero de Castilla la Vieja. Evolución demográfica en Medina del Campo durante los siglos XVI y xVII. Valladolid, 1978), en Zamora (J. RuedA FERNÁNDEZ, "La ciudad de Zamora en los siglos XVI y XVII. Estudio demográfico", Studia Zamorensia (Salamanca), 2, 1981, p. 117-134) y en Palencia (Guillermo Herrero, «La población palentina en los siglos XVI y XVII', Publicaciones del Instituto Tello Téllez de Meneses, Palencia, 21, 1961, p. 77-83). 
las negociaciones mantenidas entre los superintendentes y los diputados de los concejos, reacios en aceptar unas cuotas fiscales que, a su juicio, sólo permitían un alivio momentáneo en sus necesidades, pues para conseguir su recuperación era preciso que se moderasen a la mitad y se condonase por completo sus deudas, como así lo solicitan en todas las provincias, aunque a veces las pesquisas de los superintendentes, en su intento por conjugar los intereses de los súbditos con los del Estado, en conformidad con lo dispuesto por la Junta en su Instrucción, no confirmen plenamente las penalidades expuestas. Es el caso, en Madrid, de Valdepiélagos y la Casa de Uceda - en la primera, los encabezamientos son inferiores en un tercio a lo que devengan las alcabalas, cientos y millones; en la segunda, cada familia paga por las sisas «poco más de cuatro maravedís» ${ }^{38}-y$, en Valladolid, de Cigales, «bien reparado y [...] los vecinos de buena forma y algunos de mediano caudal» ${ }^{39}$.

Esta disparidad de criterios se agudiza a partir del mes de junio en que se dejan sentir los efectos de la sequía en los ganados y en los cultivos, arrumbadas las esperanzas de los agricultores, que ni siquiera disponen de granos para la sementera, lo que impulsará a los superintendentes a conceder descuentos más elevados, aun sabiendo que con ello no se resarcen de sus pérdidas. En los términos siguientes justifica don Pedro de Oreitia los ajustes realizados en Tierra de Campos (Valladolid): "Yo he hecho lo posible, con buena voluntad, de remitir alguna porción, asegurando otra de los débitos y dando plazos, y con harto dolor no ha sido mayor la baja en todo, porque no es creible la cortedad y pobreza que se padece en general» ${ }^{40}$. Poco más o menos se ejecutará en las restantes provincias - caso extremo es el de Córdoba, donde se moderan las alcabalas, millones y cientos en algo más de la mitad-, a menudo con la desaprobación de la Junta que no admite determinados ajustes por considerarlos lesivos para la Real hacienda, instando a los superintendentes a que los revisen, si bien sin demasiada fortuna, pues, como argumenta, entre otros, el administrador del partido de Trujillo, si se intenta renegociar los encabezamientos lo seguro es que las justicias se nieguen incluso a maniener los valores ya escriturados después de reconocer que son superiores al producto recaudado con la venta de las cosechas y ganados ${ }^{41}$.

38 AGS, CJH, Leg. 1444. Informes del superintendente de Toledo de 22 de junio, 12, 16 y 19 de julio de 1683 y Consulta del Consejo de Hacienda, 28 de julio de 1683.

39 Ibidem, Leg. 1457. Informe del superintendente de Valladolid, 17 de marzo de 1683.

$40 \mathrm{Ibidem}$, Leg. 1444. Informe del superintendente de Valladolid, 22 de mayo de 1683.

${ }^{41}$ Ibidem, Leg. 1445. Informe de don Gaspar Rodríguez de Monrroy, 10 de octubre 
A pesar de lo dicho, los pueblos no siempre obraron debidamente, inventando pretextos diversos a fin de obtener descuentos más sustanciosos. De aquí que, en ocasiones, denuncien al Consejo de Castilla presuntas irregularidades en la gestión de los superintendentes con el propósito de provocar competencias jurisdiccionales y retrasar sus diligencias, aunque por lo común procedieron a demorar, con excusas -pérdida de los libros contables-y contrapropuestas, las negociaciones de los encabezamientos, pues no desconocían la acucia de la Corona por concluir cuanto antes los ajustes para así disponer de numerario y distribuirlo entre las varias partidas del gasto público, ni los perjuicios que se le seguirían de nombrar administradores, ya que, según expone el marqués del Castillo, «habían de ser grandes e insuperables los fraudes y muy crecidos los gastos y salarios de guardas y ministros que habían de consumir, si no todo el producto y principal rendimiento de las rentas, la mayor parte ${ }^{42}$. Alguna vez solicitaron el favor de personajes influyentes en la Corte, como Carrascosa, avalada por el conde de Monterrey, o Castejón, apoyada por don Juan de Guzmán y don Francisco de Baus y

de 1683. En cuanto a Córdoba, según el ajuste realizado por don Francisco Ronquillo, el valor de las alcabalas, cientos y millones, que estaba cifrado en $55.355 .585 \mathrm{mrs}$. anuales se sitúa ahora en $29.341 .430 \mathrm{mrs}$./año, después de descontar $11.562 .406 \mathrm{mrs}$. de gastos de administración y de aplicar un 33 por ciento de rebaja sobre 43.793 .179 mrs. (libidem, Leg. 1445. Consulta de la Junta de Encabezamiento, 7 de agosto de 1683).

En la correspondencia de los superintendentes con frecuencia se reflejan las penalidades de los pueblos por la sequía del año 1683. Así, don Pedro de Oreitia informa el 20 de marzo sobre las grandes necesidades que se padecen en Tierra de Campos, en lo que insiste los días 22 y 31 de mayo (Ibidem, Leg. 1445 y 1457). Desde Carrión escribe don Antonio de la Oca Sarmiento que los vecinos han perdido sus cosechas de granos y vinos de tal modo que se han visto precisados a empeñar sus tierras para comprar "con qué volver a sembrar", toda vez que sus ganados han perecido por la falta de pastos, pues en muchos lugares "ni aun agua para beber les ha quedado". En el mes de septiembre es tan desoladora la situación que ni siquiera los religiosos del convento de San Francisco se atreven a pedir limosna. El 1 de octubre las cosas han cambiado muy poco, ya que "se va disponiendo la sementera con principios muy fatales, pues es pasado todo el mes de septiembre sin haber llovido en este partido una gota de agua, demostración que constrista el ánimo más endurecido" (Ibidem, Leg. 1445 y 1460). Recordemos dos últimos testimonios: en Jerez de la Frontera, "la mala cosecha de granos y el haberse perdido toda la del aceite son motivos que ocasionan su general desconsuelo y falta de medios" (Ibidem, Leg. 1457. Informe del corregidor, 1 de julio de 1683); por su parte don Julián de Cañas escribe el 29 de julio que los lugares de Sevilla se encuentran "sin frutos de ningún género, los vecinos fugitivos, perdidos por los campos sin tener en qué trabajar, comiendo yerbas los más virtuosos y otros robando los cortijos y ganados [...] $Y$ el mayor daño que amenaza [...] es el que no se espera sementera en el que viene [...] y esto no sólo por la falta de granos, sino de los ganados de labor, que unos han muerto de hambre y otros por el mismo temor se han llevado a las carnicerías" (Ibidem, Leg. 1444. Informe del 29 de junio de 1683).

${ }_{42}$ Ibidem, Leg. 1444. Informe del marqués de Castillo, 14 de agosto de 1683. 
Frías ${ }^{43}$. Y si sucedia que una misma provincia era encabezada por dos o más funcionarios con interpretaciones distintas de las normas elaboradas por la Junta, entonces acudían a quien más les beneficiaba o recusaban los ajustes si no se ceñían a los concertados en localidades circunvecinas, recurso que adoptan, en el partido de Alcántara (Cáceres), las villas de Arquillo, Gata, Hernán Pérez, Navasfrías, Portezuela y Villa de Torre ${ }^{44}, y$, en Jaén, la mayoría de los lugares que no se avienen a las ofertas de don Leonardo de la Cueva Cepero alegando los descuentos concedidos en Córdoba, «ejemplar que ha destroncado los buenos efectos que se pudieran lograr [...] y que no sólo ha relajado los ánimos, sino que los ha hecho insolentes" " 45 . De cuando en cuando, las ciudades y villas adoptaron actitudes más peligrosas para la seguridad del Estado, como acontece en Salamanca, donde sus capitulares van propalando entre los vecinos la idea de que subirá el precio del carnero de siete a quince cuartos y el de vaca de cuatro a siete de admitirse la oferta de don Francisco de Aguirre y Álava, Jo que le obliga a reconsiderar su propuesta ante el temor de que se produzcan altercados ${ }^{46}$. En la provincia de Madrid, la hostilidad de las justicias de Algete, Arganda, Brihuega, Campo Real, Casa de Uceda, Torrelaguna y Valdepiélagos adquiere el carácter de rebelión, hasta el punto de que el marqués de Ugena recomienda se adopten medidas severas contra los alcaldes de las villas más refractarias a los encabezamientos ${ }^{47}$. Lo mismo se observa en Ceclebín (Cáceres), donde los vecinos, no contentos con talar los árboles de una huerta propiedad de un capitán de caballos a quien el superintendente le había encomendado unas averiguaciones sobre fraudes e irregularidades en la cobranza de las rentas, le amenazan «por diversas vías que si pasaba adelante le habian de matar" ${ }^{48}$. En el partido de Ocaña (Ciudad

43 Ibidem, Leg. 1451 y 1457. Informes de don Fermín de Marichalar, 2 de junio de 1683 y de don Pedro Velluti de Haro, 23 de noviembre de 1683 . Hay que indicar que don Francisco de Baus pertenecía al Consejo de Hacienda y que don Juan Domingo de Haro y Guzmán, conde de Monterrey, era hijo de don Luis de Haro, último valido de Felipe IV y hombre de gran influencia en el Consejo de Castilla y en el de Estado (duque de Maura, Vida y reinado de Carlos II, Madrid 1942, t. II, p. 267).

44 Ibidem, Leg. 1477. Informe de don Luis Varona Ladrón de Guevara, 10 de marzo de 1684. Su propuesta consiste en rebajarles un $16 \%$ frente a la de don Luis Pacheco, superintendente de la provincia, que es del $24 \%$.

45 Ibidem, Leg. 1445. Informe del superintendente, 27 de abril de 1683.

46 Ibidem, Leg. 1444. Informes del superintendente de 7 y 14 de abril de 1683 .

47 Ibidem, Leg. 1444. Informes de los días 12, 16 y 19 de julio y Consulta de la Junta de 28 de julio de 1683 .

48 Ibidem, Leg. 1444. Informe del superintendente, 10 de marzo de 1684. La actitud belicosa de la villa viene motivada por no querer abonar el precio del encabezamiento ajustado en 1683, rechazando cuantos ejecutores despacha a este intento el superintendente. 
Real) es arcabuceada la vivienda del marqués de Ugena y acuchillado un recaudador, mientras que en Santiago de Compostela don Juan de Feloaga se ve en la necesidad de escapar embozado tras el motín desencadenado contra su persona ${ }^{49}$.

Si las exigencias de ciertas comunidades rurales tenían bastante fundamento y hasta resultaban lícitas algunas de sus artimañas, ésto no puede afirmarse cuando se trata de núcleos próximos a Madrid, importante centro de consumo y agente reactivador de las economías agrarias de su entorno ${ }^{50}$, o ciudades populosas y ricas en las que el fraude y la corrupción eran la norma. En ambos casos, el descontento, a veces muy violento, como ya hemos indicado, contra los superintendentes, venía motivado por el afán de los alcaldes y regidores de que no se alterase la administración de las rentas provinciales, en lo que a menudo contaron con el auxilio de los corregidores - así ocurre en Ávila, Cuenca, Jaén y Ronda-, atentos también a su beneficio, ya fuese por asegurarse los testigos en los juicios de residencia o por las ganancias económicas que esperaban obtener ${ }^{51}$. En Segovia, es su corregidor, don Francisco Cabeza de Vaca, quien se niega en las sesiones del ayuntamiento a que la ciudad se encabece por sus rentas, especialmente por los servicios de millones. En Valladolid - $y$ esto nos demuestra a qué grado de corrupción había llegado la justicia castellana-, es el presidente de la Chancillería quien opone mayor resistencia a las órdenes de la Junta, disconforme con el cese de los administradores y jueces conservadores y con las medidas adoptadas en las puertas de la ciudad por don Pedro de Oreitia, dispuesto a erradicar el fraude que practican ciertos ministros de la Chancillería y del Santo Oficio introduciendo en sus coches mercancías sin abonar los derechos reales, en lo que radica la negativa de los gremios a encabezarse ${ }^{52}$.

49 Para mas detalles, Juan A. SÁNCHez Belén, «El partido de Ocaña: Un caso de oposición antifiscal en La Mancha, 1665-1700", Actas I Congreso de Historia de Castilla-La Mancha, Ciudad Real 1988, t. VIII, p. 55-64.

50 DAVID R. RINGROSE, "Madrid y Castilla, 1560-1850. Una capital nacional en una economía regional», Moneda y Crédito - Madrid, n. ${ }^{\circ} 111,1969$, p. 65-122; "The impact of a New Capital City: Madrid, Toledo and New Castile, 1560-1660", Journal of Economic History, XXXIII, 1973, p. 761-791; y Madrid y la economía española, 1560-1850. Ciudad, Corte $y$ país en el Antiguo Régimen, Madrid 1985.

51 AGS, CJH, Leg. 1444-45 y 1465; AHN, Conss, Leg. 7196, exp. 29.

52 Archivo Municipal de Segovia (AMS), Libros de Acuerdos, año 1683, sesiones de los días 27/2/83, 6/3/83 y 6/4/83; AGS, CJH, Leg. 1445. Informes de don Pedro de Oreitia, 9,12 y 13 de febrero de 1683 
¿Por qué esta actitud de las justicias locales contra el encabezamiento de los pueblos si con ello se busca favorecerles? La respuesta es obvia: Si la Corona, por medio de las superintendencias, ejerce una administración más eficaz de las rentas provinciales y muy especialmente del servicio de millones, para lo cual, como hemos visto, se deben confeccionar padrones de vecindad, con mención expresa de la riqueza de sus habitantes, entonces las contribuciones serán más equitativas y se pondrá fin a los abusos de las autoridades municipales y de sus paniaguados (los grupos oligárquicos que representan), máxime cuando los débitos al erario no proceden tanto de la pobreza de los vecinos o de desembolsos circunstanciales (levas, tránsitos y alojamientos de soldados) como de malversaciones cometidas en la recaudación de los impuestos, destinado su producto, en unos casos, a gastos propios de los concejos (reparaciones de puentes, caminos o casas) y, en otros, a incrementar patrimonios personales con la compra de ganados, fincas y objetos de lujo. Los testimonios de los superintendentes son harto esclarecedores en este sentido. Así, para don Leonardo de la Cueva, el escaso apoyo que encuentra en las autoridades municipales se explica, primero, porque saben que no van a obtener salario alguno por su cooperación, "lo que les ha enfriado de suerte que más me dañan que ayudan", y, segundo, porque intentan proteger a sus conciudadanos, "teniendo en esto sus conveniencias» ${ }^{53}$. La negativa de Mayorga (Valladolid) al encabezamiento sugerido por don Pedro de Oreitia -solicita mayores rebajas y plazos más dilatados para satisfacer la deuda- se justifica tan solo porque los capitulares se han apoderado el caudal de los impuestos y sienten desembolsarlo ${ }^{54}$. En Oviedo el marqués del Castillo tropieza con idénticos inconvenientes - la deuda procede de los depositarios que se niegan a entregarle las sumas recaudadas ${ }^{55}$,

53 Ibidem, Leg. 1445. Informe del superintendente, 27 de abril de 1683.

54 Ibidem, Leg. 1457. Informe del superintendente, 31 de mayo de 1683 en donde se dice además que mantendrá por el momento el valor de lo que abonaba la villa al arrendatario, apercibiendo a los capitulares que, si en el plazo de ocho días no ingresan en la tesorería lo que deben de cientos y servicio real, despachará una audiencia a su costa para que los lleve presos a Madrid, como así lo ejecutará también con el arrendatario, don Agustín Spínola por lo que adeuda de su arrendamiento. En Cigales se observa la misma actitud, pues son sus justicias, presionadas por cierto sector acaudalado, quienes rechazan la oferta que les hace, al igual que en Benavente, donde los débitos tienen su origen en la mala administración y voluntad de los regidores. En la Puebla de Sanabria, sin embargo, los lugares admiten de buen grado el encabezamiento (sólo se les rebaja un 6 por 100) porque supone un ajuste equitativo de las cargas fiscales entre ellos y la villa, lo que antes no sucedía por el poder de sus regidores (Ibidem, Leg. 1444 y 1457. Informes de 17 de marzo y 26 y 31 de mayo de 1683).

55 Ibidem, Leg. 1444. Informe del 3 de agosto de 1683. 
mientras que en Zamora el superintendente no consigue que el regidor Juan de los Infantes ingrese en la tesorería los 2.154.851 maravedis que adeuda de cuando tuvo en administración las rentas en nombre de la ciudad ${ }^{56}$. En Jerez de la Frontera los diputados, además de rehusar la oferta del corregidor - exigen que los cientos se moderen a la mitad y las alcabalas y millones en un tercio- se niegan a confeccionar un padrón de los vecinos y a que registren sus cosechas y ganados, acostumbrados a concertar con los arrendatarios y administradores la venta de un año, puesto que así pueden, con total impunidad, defraudar los derechos reales, sobre todo en el despacho de sus vinos, cuya calidad -es el parecer del corregidor- es muy conveniente para la exportación ${ }^{57}$. En la ciudad de Jaén los hechos referidos se repiten con escasas variaciones, según se deduce del auto de encabezamiento remitido a la Junta por sus justicias y reprobado por el superintendente. A cambio de pagar 2.266.666 maravedís por el servicio de millones y ocho mil soldados y 1.133.333 maravedís por las alcabalas y cientos - un $23 \%$ inferior a lo estipulado por don Leonardo de la Cueva-, más lo que importa la refacción al estamento eclesiástico, exigen el cese de los millones acrecentados por Felipe IV, así como la facultad de ingresar los impuestos en las arcas, nombrar los ministros necesarios para la cobranza de las rentas, administrar los derechos de tal modo que los puedan minorar o incrementar cuantas veces lo consideren oportuno, repartir entre los vecinos, en caso de quiebra, el importe de lo que se debiere, arrendar las rentas por menor sin participarlo a ningún tribunal, intervenir como juzgado de primera instancia, a través del Cabildo o del corregidor y dos veinticuatros elegidos por la ciudad, en materia de fraudes, rescindir el contrato 0 rebajarlo en el supuesto de que se produzca una epidemia o cualquier otra calamidad o se decrete alguna modificación en el servicio de millones o en el sistema monetario, $y$, por último, no quedar obligadas las justicias por sus personas y bienes a la paga del encabezamiento ${ }^{58}$. La misma actitud se observa en Martos y en Andújar. En la primera, sus justicias y diez o doce individuos acomodados, «por librar sus haciendas de lo que justamente deben pagar, tienen en mal estado las cobranzas y

56 Ibidem, Leg. 1445. Informe de don Rodrígo Godínez, 23 de septiembre de 1683. La deuda procede de los meses de abril a agosto de 1683. Otros dos regidores fueron presos por este motivo pero escaparon de la cárcel y se encuentran en paradero desconocido. El superintendente solicita de la Junta que adopte las medidas oportunas para que casos similares no se repitan en adelante.

57 Ibidem, Leg. 1457. Informe de don Pedro Luis de Legasso y Porres, 2 de mayo y 1 de julio de 1683 .

58 Ibidem, Leg. 1460. Auto de Encabezamiento de la ciudad de Jaén, 17 de julio de 1683. El informe de don Leonardo de la Cueva está fechado el 11 de agosto de dicho año. 
los efectos reales, y los pobres gimen con el gran peso de la contribución", motivo por el cual el superintendente desaconseja a la Junta las demandas de la villa, toda vez que el contador ha comprobado que los débitos datan del período en que las rentas estuvieron administradas o encabezadas ${ }^{59}$. En la segunda, los capitulares se resisten a dar fianzas por el encabezamiento del servicio de millones - las alcabalas y cientos se ajustan con los gremios tras largas conservaciones- para que se ponga en administración, pues con ello esperan proseguir en sus fraudes, especialmente si su negociado se delega en el corregidor, persona noble pero "sin acción ni actividad para nada y sin estimación entre los súbditos» ${ }^{60}$.

\section{DISCREPANCIAS EN EL. GOBIERNO ANTE EL ENCABEZAMIENTO GENERAL. EL FRACASO DE LA REFORMA}

Mientras los superintendentes y sus colaboradores se esforzaban en cumplir las comisiones asignadas sin desmayo ni descanso - «aun para el corto alivio del comer y el sosegar de noche falta tiempo", escribe el contador de la superintendencia de Extremadura, don Francisco Manuel del Pozo ${ }^{61}$ - revisando, unos, las contabilidades de los pueblos, a veces en desorden por la desidia o incapacidad de los contadores y

59 Ibidem, Leg. 1445. Memorial de Cristóbal Montañés en nombre de la villa. Año 1683. El Informe del superintendente lleva fecha de 27 de abril. El argumento esgrimido por Martos para solicitar tales descuentos en las rentas es el de haberse minorado su población tras los pasados sucesos epidémicos y climáticos a 1.082 vecinos, entre los que se contabilizan 54 eclesiásticos y 391 pobres de solemnidad. Para el superintendente, sin embargo, el descenso de su vecindario data desde 1652, habiéndose reducido desde esta fecha en 700 vecinos. Por otra parte, según las averiguaciones realizadas por el contador de la superintendencia, las rentas han ido disminuyendo progresivamente desde 1678, pues entre septiembre de este año y junio de 1679 se arrendaron en 1.340 .367 maravedís; el encabezamiento para el período $1680-85$ se concertó en 1.190.000 maravedís anuales y su administración, por quiebra de la villa, sólo produjo 990.782 maravedís anuales (Jbidem, Relación del valor de las rentas de la villa de Martos, 26 de abril de 1683).

60 Ibidem, Leg. 1444. Informe de 26 de mayo de 1683. El 5 de enero de 1684 informa el superintendente que se están «arrendando" y "componiendo" las alcabalas y cientos de la ciudad, lo que demuestra que el ajuste realizado en 1683 con los gremios sólo tuvo de duración un año (Ibidem, Leg. 1477).

61 Ibidem, Leg. 1444. Informe de 22 de mayo de 1683. 
escribanos ${ }^{62}$, y soportando, otros, entrevistas infructuosas con los diputados de los concejos, cuando no obstrucciones y atentados procedentes de las oligarquías ciudadanas ${ }^{63}$, en Madrid determinados sectores del gobierno comienzan a cuestionar las ventajas del encabezamiento general del Reino. El primer toque de atención se produce a finales del mes de julio de 1683, protagonizado por el presidente del Consejo de Hacienda, el conde de Humanes, y por don Diego de Cetina, de la Sala de Millones, descontentos con las bajas otorgadas en Córdoba. La Junta, sin embargo, reunida el 7 de agosto en sesión extraordinaria aprobará por mayoría (votos de don Gil de Castejón, don Carlos de Villamayor, don Luis Moreno Ponce de León y don Juan Ignacio Bautista de Rivas) la gestión del superintendente de Córdoba, porque en el ajuste realizado se garantiza a los juristas y demás acreedores el pago de sus intereses sobre estas rentas - hemos de indicar que el problema de la deuda pública fue esgrimido continuamente por quienes eran contrarios a cualquier innovación que se abordase en el sistema fiscal de la Monarquía-, porque las justicias se comprometen como particulares al pago del encabezamiento, y porque, concediendo «al Reino todo el alivio que cupiere en lo posible", se alienta entre los súbditos el fomento de las actividades económicas, de donde se originarán para el Estado ingresos más cuantiosos «en las mismas rentas para los años de adelante» ${ }^{64}$.

Aunque estas razones fueron aceptadas por la Corona, lo cierto es que a comienzos de 1684 el duque de Medinaceli solicita del conde de Humanes su parecer sobre los efectos positivos o negativos del encabezamiento y más en particular acerca de sus repercusiones en los ingresos reales - el motivo de la consulta venía condicionado por la necesidad de allegar fondos para la provisión de los ejércitos de Flandes tras el nuevo conflicto desencadenado por Luis XIV en noviembre de 1683-. La

\footnotetext{
62 El retraso del encabezamiento de Llerena, escribe el superintendente de Extremadura, es atribuible, por un lado, a la falta de papeles ante «la continua embriaguez» del escribano de la ciudad y, por otro, a la inhabilidad del contador que le acompaña, don Andrés Dávila, que ha empleado tres meses en confeccionar una relación de las rentas del partido (/bidem, Leg. 1445. Informe de 23 de septiembre de 1683).

63 "Gracias a Dios - escribe don Francisco de Aguirre y Álava- se ha conseguido el encabezamiento de millones de la ciudad... después de las batallas que nos ha costado, en que se ha trabajado con fuerza, con maña y con prudenciales medios para que lleguen a proporción capaz de admitirse» (/bidem, Leg. 1444. Informe de 14 de abril de 1683). Expresiones similares leemos en la correspondencia de los restantes superintendentes. Sirva como demostración la de don Juan de la Hoz Mota desde Granada o la de don Leonardo de la Cueva Cepero desde Jaén (Ibidem, Leg. 1444 y 1960).

64 Ibidem, Leg. 1462. Consulta de la Junta de Encabezamientos, 7 de agosto de 1683.
} 
respuesta del presidente de Hacienda de que apenas habían descendido los valores de las rentas provinciales respecto al quinquenio último ${ }^{65}$ no consigue despejar las dudas de los detractores de la reforma, puesto que el rechazo de las justicias locales a los encabezamientos produjo, por un lado, la moratoria en las cobranzas y, con ello el retraso en las pagas de los acreedores y en la financiación de la maquinaria gubernamental; por otro, el que los superintendentes flexibilicen sus ofertas, adecuándolas a las exigencias de las ciudades y villas -es lo que acontece, por ejemplo, en Oviedo y Salamanca ${ }^{66}$-; y, por último, el que la Junta, ante las negativas reiteradas a los ajustes, opte por designar administradores aun a riesgo de que los valores de las rentas disminuyan, toda vez que hacia 1684 permanecian sin encabezar algunos núcleos importantes de Andalucía (en Jaén, además de los casos referidos podríamos citar los de Baeza y Úbeda; en Málaga, la ciudad de Ronda; y en Cádiz, Jerez de la Frontera) y la casi totalidad de las provincias de Extremadura, Galicia, Sevilla y Toledo, precisamente aquellas que por su proximidad a la frontera portuguesa, su ubicación marítima, su tráfico comercial con América o con el norte de Europa, su cercanía a la Corte o la relevancia de su clero eran auténticos avisperos de contrabandistas y metedores, entre los que, por supuesto, se encontraban clérigos, caballeros de las Órdenes Militares y ministros del Santo Oficio que, al amparo de sus exenciones y privilegios, pretendían excusar el pago de los tributos, haciendo caso omiso de las leyes del Reino o de lo dispuesto en los breves Apostólicos concedidos al monarca por la Santa Sede. Así, pues, el 28 de febrero de 1684 se va a ordenar al Consejo de Hacienda y a la Sala de Millones que arbitren las medidas correctivas adecuadas para atajar los inconvenientes derivados de la inobservancia de la Instrucción de 1682, ya que, como se dice, los superintendentes en general se han excedido otorgando rebajas, con el peligro de:

«... descubrir a los pueblos el camino de que con no pagar y dejar crecer la deuda pueden esperar nuevas remisiones, habiendo perdido

65 Ibidem, Leg. 1477. Consulta del presidente de Hacienda (s. f.) pero de 1684.

66 En Oviedo, el superintendente accede a rebajar las rentas en un $24 \%$ respecto al período anterior, modificando su oferta inicial que era de un $16 \%$ (lbidem, Leg. 1444. informe de 14 de agosto de 1683). En Salamanca, el servicio de millones fue tasado por don Francisco de Aguirre en 7.000.000 de maravedís anuales más la refacción al estamento eclesiástico por cuenta de la ciudad, lo que es rechazado por ésta, aviniéndose al fin a que pague 6.500.000 maravedís al año y 538.844 maravedis en que es estimado el importe de la refacción, estipulándose que si ésta fuera superior la Corona abonará la diferencia y si sucediese lo contrario sería en mayor beneficio de la Real Hacienda (Ibidem, Leg. 1444. Informes de 7 y 14 de abril de 1683). 
el miedo a los apremios con haberse hecho pública la orden [...] que se dió a los administradores para no despachar ejecutores ni audiencias, y que al mismo tiempo se han quedado los poderosos consentidos en su excepción y los pobres con las cargas de antes. $Y$ habiendo más de un año que se entiende en estas diligencias sólo están ajustadas enteramente once provincias y las más con los achaques referidos ${ }^{67}$.

¿Cuál fue el dictamen del Consejo de Hacienda junto con la Sala de Millones? Después de varias sesiones, lo que demuestra el contraste de ideas entre sus miembros, la mayoría concluye admitiendo que la reforma ha fracasado y, por consiguiente, se debe rechazar su continuidad en el futuro, arrendándose con la mayor cuantía posible, no obstante las quejas de los pueblos, aquellas rentas que aún permanecen sin encabezar - para el marqués de la Vega, que emitió voto aparte, se deben arrendar incluso las encabezadas o, en el supuesto de no haber nadie que las contrate, se comisione su administración a los corregidores, supervisados por el Consejo de Hacienda sin interponerse ningún tribunal 0 , si se prefiere, por la Cámara de Castilla, siempre que su presidencia recaiga en el gobernador de Hacienda ${ }^{68}$ - y exigiéndose, según la propuesta de don Pedro de Porres, responsabilidades a los superintendentes, aun cuando se reconoce en términos globales su celo por ejecutar con fidelidad las normas elaboradas por la Junta. Las razones de este fracaso, empero, no resultan convincentes, pues, tras ignorar o minimizar los efectos de las malas cosechas de 1683 y de las inundaciones que sobrevinieron a finales del año en Andalucía y en otras regiones castellanas - sólo el marqués de la Vega aventura un factor decisivo, la escasez de moneda circulante-, se resalta, por un lado, la malicia de los pueblos que, "abusando de la piedad de V. Majestad", solicitan nuevas rebajas o se retraen de ingresar en las arcas y tesorerías lo que deben contribuir a fin de obtener futuras condonaciones, cosa que no sucede cuando las rentas se arriendan, porque sus beneficiarios las consideran «hacienda propia suya" y como tal las administran, reclamando su pago puntual,

67 Ibidem, Leg. 1476. Real Decreto de 28 de febrero de 1864.

68 Ibidem, Leg. 1476. Consulta del Consejo de Hacienda en Sala de Miliones, 10 de abril de 1684, voto particular del marqués de la Vega. Los ministros que participaron en la discusión fueron, además del susodicho, el conde de Humanes, presidente del Consejo, los marqueses de Castromonte, Olmeda y Ugena, el conde de Guaro, don Agustín Spínola, don Luis Moreno Ponce de León, don Juan de la Hoz Mota, don Pedro de Porres, don Juan de Feloaga, don Luis del Hoyo, don Francisco de Baus, don Juan Ignacio Bautista de Rivas, don Antonio de Camporrells, don Francisco de Guadalfajara y don Antonio de la Vega. 
«ya con apremios y ya con equidad»; por otro, los perjuicios que la Corona recibe, tanto por ver disminuidos sus ingresos con los valores ajustados, como por las consecuencias dimanadas del cese de los arrendatarios, ya que no hay nadie que se comprometa a prestar el capital necesario para las provisiones de los ejércitos y demás gastos inmediatos, "desconfiados de tomar libranzas en las arcas por no asegurarse la satisfacción de ellas» ${ }^{69}$.

Contra esta visión negativa, en la que los tópicos enmascaran una ofensiva de los arrendatarios y asentistas hacia el encabezamiento general, se alzó un sector reducido del Consejo de Hacienda para el cual no hay ningún argumento que justifique un retorno al pasado - sólo si los pueblos persisten en su actitud de recusar los ajustes entonces se podrán suscribir arriendos, pero con la condición de que sean por el conjunto de las rentas provinciales para evitar la multiplicidad de ejecutores, especificándose en los contratos las cantidades que corresponden a cada una con el fin de facilitar los pagos a los acreedores $y$ librancistas ${ }^{70}$ - y sí, en cambio, varios que aconsejan se prosiga con el sistema recién instituido, ya que el cese de los arrendatarios, a menudo faltos de liquidez, y la presencia de los superintendentes al frente de la administración y colecturia de los impuestos supone el final de las extorsiones de los pueblos, libres de crecidos encabezamientos y de las costas que les ocasionan los ejecutores despachados a las cobranzas, factor clave, en opinión de don Agustín Spínola, de su incapacidad tributaria ${ }^{71}$, así como ingresos más saneados para el Estado por lo antedicho, pero también por no tener que abonar intereses por los anticipos ofrecidos en los arriendos, aumentando de este modo su solvencia, lo que redundará en beneficio de los acreedores, especialmente de los hombres de negocios, dispuestos a conceder con más facilidad nuevos asientos, toda vez que las justicias de los lugares garantizan con sus haciendas el pago de los impuestos en los plazos estipulados, si bien a juicio de don Juan Ignacio Bautista de Rivas, la razón por la cual los acreedores no perciben con prontitud las cantidades adeudadas por la Corona reside en la inobservancia por el Consejo de Hacienda y la Sala de Millones de dos requisitos imprescindibles: librar «con cuenta cada caudal de por sí y no a bulto y mezclando unos con otros" y no autorizar el despacho de "más

69 Ibidem, Leg. 1476. Consulta del Consejo en Sala de Millones, 10 de abril de 1684.

70 Ibidem, Votos particulares de don Agustín Spínola y de don Francisco de Guadalfajara.

Ibidem, Voto particular de don Agustín Spínola. 
libranzas que las que quepan en su valor, que de esta suerte $[. .$.$] tendrá$ el asentista más puntual satisfacción de su libranza y se ahorrarán muchos intereses a la Real Hacienda» ${ }^{72}$.

Por otro lado, y aparte de consideraciones políticas —si la Corona, sostiene don Francisco de Guadalfajara, desea obtener la confianza de los súbditos y de los grupos financieros, es preciso que "no se haga novedad en nada lo resuelto" ${ }^{73}$ - este sector rechazará por infundadas las acusaciones que se formulan contra los superintendentes de arbitrariedad y morosidad en el ajuste de las provincias, tanto porque son diecisiete y no once las que están encabezadas y en las demás se espera que concluirán en breve los encabezamientos, aun cuando algunos lugares de Sevilla y Toledo queden en administración, como porque las rebajas otorgadas en las alcabalas, cientos y millones no han superado el $12 \%$, según se desprende de un sumario elaborado por la contaduría de relaciones en el mes de junio de $1683^{74}$.

72 Ibidem, Votos particulares de don Agustín Spínola, don Francisco de Guadalfajara, don Luis Moreno Ponce de León y don Juan Ignacio Bautista de Rivas.

${ }_{73}$ Ibidem, Votos particulares de don Francisco de Guadalfajara y don Juan Ignacio Bautista de Rivas.

${ }^{74}$ Ver nota 72 . Los valores de las rentas provinciales encabezadas en el mes de junio de 1683 son los siguientes:

\begin{tabular}{|c|c|c|c|c|c|c|c|}
\hline \multirow[b]{2}{*}{ Provincias } & \multirow[b]{2}{*}{ Lugares } & \multicolumn{2}{|c|}{$\begin{array}{c}\text { Alcabalas, cientos y millones } \\
\text { (en mrs) }\end{array}$} & \multirow{2}{*}{$\begin{array}{l}\text { Rebaja } \\
(\%)\end{array}$} & \multirow{2}{*}{$\begin{array}{l}\text { Débitos } \\
\text { (mrs) }\end{array}$} & \multirow{2}{*}{$\begin{array}{l}\text { Remisiones } \\
\text { (mrs) }\end{array}$} & \multirow{2}{*}{$(\%)$} \\
\hline & & $\begin{array}{l}\text { Valores } \\
\text { antiguos }\end{array}$ & $\begin{array}{l}\text { Valores } \\
\text { modernos }\end{array}$ & & & & \\
\hline Ávila & 290 & 57.012 .081 & 57.992 .699 & +1 & 55.176 .720 & 5.885 .431 & 10 \\
\hline Córdoba & 49 & 49.970 .206 & 35.856 .797 & 29 & - & - & - \\
\hline Cuenca & 212 & 69.495 .808 & 61.205 .287 & 12 & - & - & - \\
\hline Guadalajara & 83 & 17.224 .671 & 14.441 .124 & 17 & - & - & - \\
\hline Madrid & 92 & 150.837 .090 & 148.753 .810 & 2 & - & - & - \\
\hline Murcia & 60 & 47.203 .873 & 37.386 .625 & 21 & 60.610 .294 & 3.433 .260 & 5 \\
\hline Palencia & 285 & 38.271 .065 & 39.903 .057 & +4 & 48.438 .559 & 4.329 .548 & 9 \\
\hline Salamanca & 461 & 72.894 .577 & 62.071 .141 & 15 & - & - & - \\
\hline Segovia & 226 & 42.939 .454 & 40.256 .677 & 7 & 8.014 .151 & 3.643 .280 & 55 \\
\hline Soria & 457 & 42.528 .411 & 29.980 .699 & 30 & 36.383 .361 & 17.939 .512 & 51 \\
\hline Toro & 45 & 19.643 .929 & 15.263 .117 & 23 & - & - & - \\
\hline Toledo & 142 & 66.534 .330 & 59.219 .309 & 11 & - & - & - \\
\hline Valladolid & 416 & 115.742 .400 & 97.712 .241 & 16 & 73.718 .623 & 20.426 .394 & 27 \\
\hline Total & 2.818 & 790.297 .850 & 700.042 .510 & 12 & 282.741 .708 & 55.657 .425 & 20 \\
\hline
\end{tabular}

(Fuente: AGS, Cont. Gles., Leg. 3928. Sumario de las ciudades villas y lugares que se han encabezado en las veintiuna provincias del reino, según consta de los avisos que han dado los superintendentes... hasta 22 de junio de 1683.) 
Esta estimación, desde luego, se aproxima bastante a los resultados finales. Si comparamos lo que abonaban las provincias por alcabalas y cientos antes de 1683 con los valores encabezados a partir de este año (cuadro I), observaremos que la diferencia fue tan solo del $18 \%$, recayendo las mayores rebajas en los cientos - globalmente esta renta desciende en un $20,8 \%$ frente al $14,8 \%$ en que lo hacen las alcabalas-y en las provincias de la submeseta meridional, las más afectadas por la crisis de los años 1677-83, aunque entre ellas, como entre las de la mitad norte peninsular, hubo algunas que obtuvieron descuentos más notorios y, dentro de ellas, ciertos partidos e incluso localidades. Así, en Madrid, mientras las alcabalas y cientos apenas experimentan variaciones entre 1682 y 1683 , éstas, en el servicio de millones, oscilan en torno al $8 \%$, excluido el partido de Alcalá de Henares, que pertenecía a Toledo, y las villas de Móstoles y Vallecas - la primera se encabezó en 1684 y la segunda se puso en administración- (cuadro II). En contraposición a este moderado descuento hay que mencionar las bajas otorgadas a Murcia, Guadalajara y Cuenca -entre el 11 y el $16 \%$ en sus alcabalas y cientos pero no así en el servicio de millones-, logrando algunas poblaciones, como la villa de Hornos (Murcia) o El Vellón (Guadalajara) rebajas superiores: en la primera, el encabezamiento del servicio se modera en un $52,6 \% \mathrm{y}$, en la segunda, en un $18 \%{ }^{75}$. En Granada, las rentas provinciales, exceptuando el servicio de millones, se reducen en un $35 \%$ y en Córdoba en casi la mitad ${ }^{76}$. Poco más o menos acontece en la submeseta septentrional. En Valladolid, las alcabalas y cientos sólo disminuyen un $8 \%$, aunque el total de las rentas provinciales lo hace en un $11 \%$, llegando al 30 y $47 \%$ en poblaciones muy deprimidas como Robledillo, Traspinedo, Villalba de la Loma, Villanueva de Esgueva, Villar de Tordesillas y Zorita de la Loma (cuadros III y IV). En Salamanca, por el contrario, el conjunto de las rentas se minora en un $8 \%$, pero las alcabalas y cientos lo hacen en un $19 \%{ }^{77}$. En León, incluidos los partidos de Ponferrada y Oviedo, se repite el mismo fenómeno: rebaja de un $12 \%$ del total de sus rentas y de un $16 \%$ en las alcabalas y cientos ${ }^{78}$. En Tuy, sin embargo, el duque de Uceda modera las alcabalas, cientos y diezmos en un $25 \%$ y el servicio de millones en un $29 \%$ atendiendo a su cercanía con Portugal y a que sus vecinos asisten a las guarniciones de las plazas fuertes con cuatrocientos

\footnotetext{
75 AGS, $C J H$, Leg. 1444. Informe de 26 de octubre de 1683 y Leg. 1445. Informe del 23 de julio de 1683.

76 Sobre Córdoba, ver nota 41 y compararla con los datos del cuadro I.

AGS, CJH, Leg. 1465. Informe de 12 de febrero de 1684.

78 Ibidem, Leg. 1460. Informe de 4 de marzo de 1684.
} 
hombres ${ }^{79}$. En Soria, los descuentos fueron aún superiores, oscilando en torno al $30 \%$, sin apenas diferencias entre las varias rentas provinciales, justificado por la escasa prosperidad de sus poblaciones (cuadro $\mathrm{V}$ ), lo que también sucede en el partido de Reinosa, antigua provincia de Toro ${ }^{80}$.

En cuanto a las deudas, lo usual fue minorarlas entre un 20 y un $30 \%$, llegándose incluso al 50 o al $100 \%$ en determinados lugares de

79 Ibidem, Leg. 1457. Informe de 29 de octubre de 1683.

80 Ibidem, Leg. 1451. Informe de 23 de noviembre de 1683. En el partido de Reinosa, los encabezamientos antiguos y modernos de veintiocho lugares fueron los siguientes:

\begin{tabular}{|c|c|c|c|}
\hline \multirow{2}{*}{ Localidad } & \multicolumn{2}{|c|}{$\begin{array}{c}\text { Alcabalas, tercias, cientos y millones } \\
\text { (en mrs) }\end{array}$} & \multirow{2}{*}{$\begin{array}{c}\text { Rebaja } \\
(\%)\end{array}$} \\
\hline & Valores antiguos & Valores modernos & \\
\hline Abiada & 60.448 & 34.500 & 43 \\
\hline Camasa & 43.578 & 29.303 & 32 \\
\hline Caserillo & 53.213 & 38.236 & 28 \\
\hline Camino & 55.515 & 34.918 & 37 \\
\hline Celada de los Calderones & 53.903 & 35.936 & 33 \\
\hline Espinilla & 15.989 & 11.993 & 25 \\
\hline Espinosilla & 3.902 & 2.842 & 27 \\
\hline Fontibre & 50.553 & 25.276 & 50 \\
\hline Izara & 56.475 & 40.644 & 28 \\
\hline Loma, La & 5.560 & 4.171 & 25 \\
\hline Mata & 67.633 & 39.139 & 42 \\
\hline Mata de Hoz, Lugares de & 5.947 & 4.462 & 25 \\
\hline Mina & 45.716 & 30.478 & 36 \\
\hline Olea con su barrio & 10.985 & 5.492 & 50 \\
\hline Olmos & 35.427 & 24.545 & 31 \\
\hline Paracuellos & 30.221 & 21.564 & 29 \\
\hline Población & 14.545 & 10.909 & 25 \\
\hline Campo de Suso & 39.157 & 27.724 & 29 \\
\hline Pruano & 57.212 & 40.096 & 30 \\
\hline Quintanillas & 58.254 & 39.478 & 32 \\
\hline Reinosilla & 12.495 & 9.372 & 25 \\
\hline Salces & 48.529 & 28.825 & 40 \\
\hline Santa Olalla & 1.645 & 1.148 & 30 \\
\hline Soto & $67.662(1)$ & 41.652 & 38 \\
\hline Suano y venta de Soma Hoz & 84.317 & 59.809 & 29 \\
\hline Venta de Mostajo & $7.178(2)$ & 5.158 & 33 \\
\hline Villacantis & 82.519 & 55.014 & 33 \\
\hline Villasuso & 53.076 & 35.380 & 33 \\
\hline Total & 1.061 .188 & 738.064 & 31 \\
\hline
\end{tabular}

Fuente: AGS, CJH, Leg. 1451.

(1) Sin las alcabalas.

(2) La elevada suma que paga el ventero está en relación con el consumo de los caminantes. 


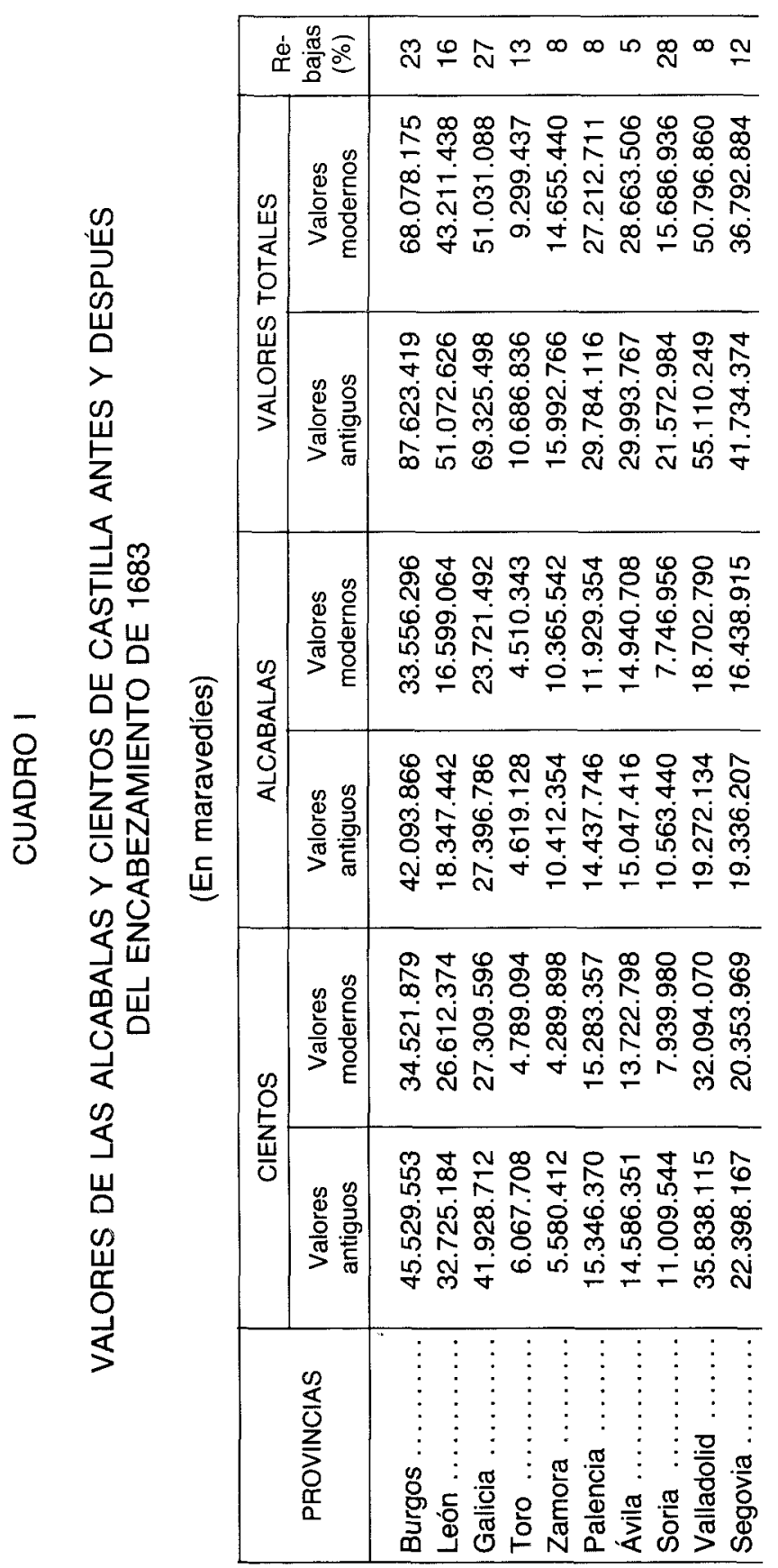


Absolutismo y fiscalidad en Castilla a fines del siglo XVII...

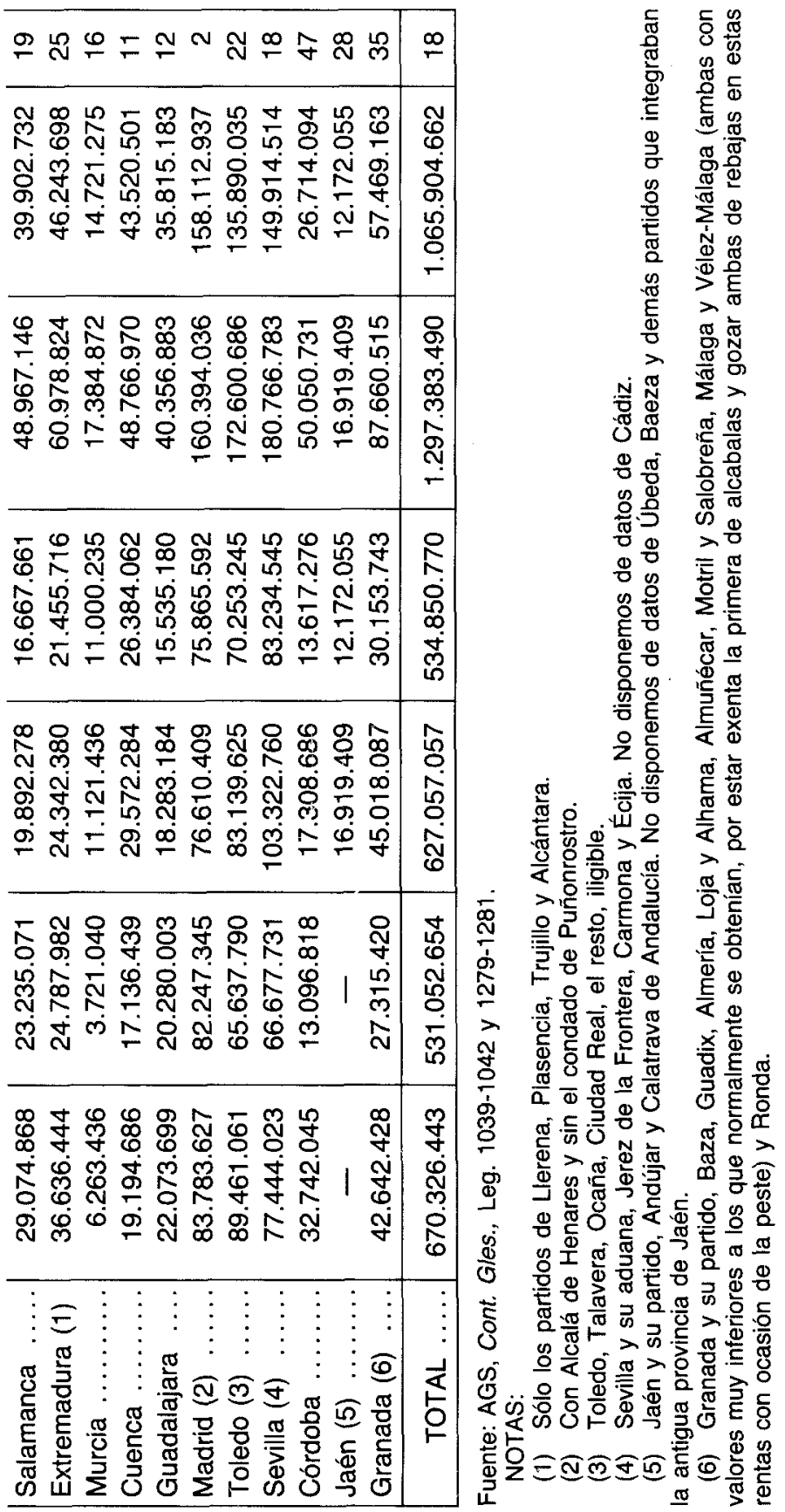




\section{CUADRO II}

\section{RELACIÓN DE VALORES DEL SERVICIO DE MILLONES DE LA PROVINCIA DE MADRID ANTES Y DESPUÉS DEL ENCABEZAMIENTO DE 1683}

(En maravedies)

\begin{tabular}{|c|c|c|c|c|}
\hline LOCALIDAD & $\begin{array}{c}\text { Encabezamiento } \\
\text { hasta } 1678\end{array}$ & $\begin{array}{c}\text { Encabezamiento } \\
\text { desde } 1683\end{array}$ & Rebaja & $\%$ \\
\hline Alameda & 126.400 & 126.400 & - & - \\
\hline Alcobendas ... & 266.000 & 266.000 & - & 一 \\
\hline Alcorcón & 311.000 & 311.000 & - & 一 \\
\hline Aimoguera $\ldots . . . \ldots$. & 54.760 & 54.760 & - & - \\
\hline Alocen & 77.500 & 77.500 & - & 一 \\
\hline Alóndiga & 62.000 & 62.000 & - & - \\
\hline Alvares $\ldots \ldots \ldots \ldots$. & 114.540 & 114.540 & - & - \\
\hline Aravaca & 228.506 & 228.506 & - & 一 \\
\hline Arroyomolinos. & 32.244 & 32.244 & - & - \\
\hline Alvalate $\ldots . . .$. & 99.000 & 69.125 & 29.875 & 30 \\
\hline Almonacid de Zorita & 140.000 & 122.500 & 17.500 & 13 \\
\hline Álamo, El .......... & 70.200 & 68.000 & 2.200 & 3 \\
\hline Ambroz $\ldots \ldots \ldots \ldots$ & 4.376 & 3.376 & 1.000 & 23 \\
\hline Auñón. & 247.983 & 230.983 & 17.000 & 7 \\
\hline Barajas ............ & 527.000 & 544.000 & +17.000 & +3 \\
\hline Belmonte del Tajo ... & 82.000 & 80.000 & 2.000 & 3 \\
\hline Berlinches .......... & 81.610 & 81.610 & - & 一 \\
\hline Boadilla $\ldots \ldots \ldots \ldots$ & 10.000 & 10.000 & - & - \\
\hline Brea ... & 70.416 & 70.416 & - & - \\
\hline Brunete. & 351.568 & 306.000 & 45.568 & 13 \\
\hline Buendía & 300.000 & 249.000 & 51.000 & 17 \\
\hline Cabeza, La & 5.122 & 5.122 & - & - \\
\hline Canillas $\ldots \ldots \ldots \ldots$ & 5.000 & 5.000 & - & - \\
\hline Canillejas ........... & 100.000 & 90.000 & 10.000 & 10 \\
\hline Carabanchel de & & & & \\
\hline Abajo .......... & 1.040 .400 & 986.000 & 54.400 & 5 \\
\hline Carabanchel de & & & & \\
\hline Arriba $\ldots \ldots \ldots$ & 544.000 & 544.000 & - & - \\
\hline Casarrubuelos & 19.627 & 19.627 & - & - \\
\hline Casarrubios del & & & & \\
\hline Monte ....... & 510.000 & 459.000 & 51.000 & 10 \\
\hline Camarma ... & 170.000 & 131.467 & 38.533 & 23 \\
\hline Coslada .. & 19.708 & 19.708 & - & - \\
\hline Cubas. & 34.000 & 34.000 & 一 & - \\
\hline Dubres $\ldots . . . \ldots \ldots$. & 40.396 & 38.000 & 2.396 & 6 \\
\hline Escariche ........... & 42.372 & 42.372 & - & - \\
\hline
\end{tabular}


Absolutismo y fiscalidad en Castilla a fines del siglo XVII...

\begin{tabular}{|c|c|c|c|c|}
\hline LOCALIDAD & $\begin{array}{c}\text { Encabezamiento } \\
\text { hasta } 1678\end{array}$ & $\begin{array}{c}\text { Encabezamiento } \\
\text { desde } 1683\end{array}$ & Rebaja & $\%$ \\
\hline Escopeta & 25.732 & 12.000 & 13.732 & 53 \\
\hline Fuencarral .......... & 321.000 & 321.000 & - & - \\
\hline Fuenlabrada ......... & 570.000 & 570.000 & - & - \\
\hline Fuente la Encina & 246.000 & 237.500 & 8.500 & 3 \\
\hline Fuentenovilla ... & 43.146 & 43.146 & - & - \\
\hline Chamartín ........... & 8.000 & 8.000 & - & - \\
\hline Griñón $\ldots \ldots \ldots \ldots \ldots$ & 97.174 & 97.174 & - & - \\
\hline Gruba $\ldots \ldots \ldots \ldots$ & 50.222 & 50.222 & - & 一 \\
\hline Hortaleza ... & 100.000 & 100.000 & - & - \\
\hline Húmera & 30.000 & 30.000 & - & 一 \\
\hline Illana ... & 64.000 & 60.000 & 4.000 & 6 \\
\hline Getafe..$\ldots \ldots \ldots \ldots$ & 3.029 .660 & 2.504 .984 & 524.676 & 17 \\
\hline Leganés .............. & 992.800 & 992.800 & - & - \\
\hline Majadahonda ......... & 269.366 & 195.500 & 73.866 & 27 \\
\hline Mazuecos .......... & 20.000 & 20.000 & - & - \\
\hline Mejorada ............ & 53.303 & 53.303 & - & 一 \\
\hline Moraleja de Enmedio & 30.000 & 30.000 & - & 一 \\
\hline Moraleja la Mayor ... & 2.448 & 2.448 & - & 一 \\
\hline Moratilla .............. & 68.884 & 68.884 & - & - \\
\hline Odón $\ldots \ldots \ldots \ldots \ldots$ & 110.000 & 104.000 & 6.000 & 5 \\
\hline Ontova ..... & 56.614 & 49.537 & 7.077 & 12 \\
\hline Parla ....... & 270.000 & 250.000 & 20.000 & 7 \\
\hline Pastrana $\ldots . . . \ldots \ldots$ & 664.000 & 616.000 & 48.000 & 7 \\
\hline Pedrezuela .......... & 21.517 & 21.517 & - & - \\
\hline Perales ............... & 6.120 & 6.120 & - & - \\
\hline Pozo de Almoguera & 9.554 & 9.554 & - & 一 \\
\hline Peñalver ........... & 72.000 & 70.000 & 2.000 & 2 \\
\hline Pozuelo de Alarcón & 127.800 & 127.800 & - & - \\
\hline Quijorna ............. & 61.200 & 61.200 & - & - \\
\hline Quismundo .......... & 57.000 & 57.000 & - & - \\
\hline Rejas ...... & 50.000 & 50.000 & 一 & 一 \\
\hline Rivas ....... & 20.400 & 12.000 & 8.400 & 41 \\
\hline Rozas, Las .......... & 300.236 & 300.236 & - & - \\
\hline Retamosa .......... & 30.796 & 30.796 & - & - \\
\hline Sacedón ......... & 51.000 & 47.600 & 3.400 & 7 \\
\hline San Agustín & 132.500 & 132.500 & - & - \\
\hline San Sebastián de los & & & & \\
\hline Reyes...$\ldots \ldots \ldots$ & 106.400 & 106.400 & - & - \\
\hline Santa Cruz de & & & & \\
\hline Retamar ...... & 35.536 & 35.536 & - & 一 \\
\hline Sayatón .... & 20.534 & 20.534 & - & - \\
\hline Serranillos & 55.720 & 55.720 & - & 一 \\
\hline Torrejón de Velasco & 838.100 & 637.500 & 200.600 & 24 \\
\hline Torrejón de la Riveral & 27.200 & 23.800 & 3.400 & 13 \\
\hline
\end{tabular}


JUAN A. SÁNCHEZ BELÉN

\begin{tabular}{|c|c|c|c|c|}
\hline LOCALIDAD & $\begin{array}{c}\text { Encabezamiento } \\
\text { hasta } 1678\end{array}$ & $\begin{array}{c}\text { Encabezamiento } \\
\text { desde } 1683\end{array}$ & Rebaja & $\%$ \\
\hline $\begin{array}{l}\text { Torrejoncillo de la } \\
\text { Calzada } \ldots \ldots \ldots\end{array}$ & 46.000 & 43.000 & 3.000 & 7 \\
\hline Vaciamadrid ......... & 47.600 & 47.600 & - & - \\
\hline Valdeconcha $\ldots . . .$. & 58.222 & 58.222 & - & - \\
\hline Val de Santo Domingo & 124.422 & 114.750 & 9.672 & 8 \\
\hline Valmojado ...... & 34.000 & 34.000 & 一 & - \\
\hline Velilla .... & 20.400 & 20.400 & - & 一 \\
\hline Venta de Aravaca & 10.100 & 10.100 & - & 一 \\
\hline Venta de Alcorcón. & 10.200 & 10.200 & - & 一 \\
\hline Venta de Branigal ... & 5.100 & 5.100 & - & $\longrightarrow$ \\
\hline Vicálvaro ......... & 898.191 & 816.000 & 82.191 & 9 \\
\hline Villamanta & 100.000 & 80.000 & 20.000 & 20 \\
\hline Villaverde & 448.800 & 448.800 & - & - \\
\hline Yebra ... & 82.903 & 82.903 & - & - \\
\hline Zarzuela, La & 60.000 & 30.400 & 29.600 & 49 \\
\hline TOTAL. & 16.879 .630 & 15.506 .042 & 1.373 .588 & 8 \\
\hline
\end{tabular}

Fuente: AGS, CJH, Leg. 1451. 24 millones de la provincia de Madrid. Relación de lo en que estaban encabezadas las villas y lugares hasta fin de marzo de 1678 antes de la baja de moneda de 1680, las cantidades en que ahora se han ajustado desde 1 de abril de 1683 y diferencias que hay de uno a otro... aprobadas por la Junta. Madrid, 12 de agosto de 1683. 
Granada, Salamanca, Soria y Valladolid, pues, como informa don Juan de la Hoz Mota, «ninguna cosa imposibilita tanto las cobranzas corrientes como las deudas atrasadas, siendo éstas las que totalmente arruinan y destruyen los lugares» ${ }^{81}$, idea que representa a su vez don Francisco de Aguirre y Álava cuando escribe: «creyera por más útil fuesen más crecidas las bajas, por reconocer que estos atrasos los han de imposibilitar para los débitos corrientes y que no cabe en su necesidad pagar dos o más años juntos» ${ }^{82}$.

El dictamen del monarca, inserto en la consulta mencionada del Consejo de Hacienda, fue el de no innovar los encabezamientos de las provincias ajustadas, si bien se recomienda a los superintendentes que cada mes remitan un resumen de los cobros efectuados, indicando lo que corresponde a las rentas encabezadas y a los débitos, lo que fuere entrada por salida y lo ingresado efectivamente en las arcas y tesorerías, apercibiéndoseles que de no ejecutarlo se procederá contra sus personas en la forma acostumbrada. En aquellas provincias o localidades donde todavía prosiguen las negociaciones se podrán concertar arriendos bajo la supervisión del Consejo de Hacienda o de la Sala de Millones, que deben procurar corregir los abusos «a que hasta ahora ha obligado la necesidad, que, aunque al presente es tan grande, importa ir poniendo estas materias en regla» ${ }^{83}$. Con esta resolución la Corona venía a ratificar lo ejecutado por la Junta de Encabezamientos y, en definitiva, lo obrado por los superintendentes -en la práctica, sin embargo, durante todo el año 1684 se revisarán ciertos ajustes, como el de la villa de Navarrete que, encabezada por don Pedro Velluti de Haro en 590.958 $\mathrm{mrs}$, se la hace pagar ahora $794.000 \mathrm{mrs}$, cifra más próxima a la que satisfacía en años anteriores, unos $981.200 \mathrm{mrs}^{84}$, prevaleciendo así las opiniones de los partidarios de la reforma, toda vez que, con palabras de don Francisco de Guadalfajara,

«si V. M. no hubiese tomado esta forma puede persuadirse había de estar el Reino en mayor congoja y la Real Hacienda con menos valor por las bajas que se hacía a algunos pueblos y las mayores a los

\footnotetext{
81 Ibidem, Leg. 1465. Informe de don Juan de la Hoz Mota, 24 de agosto de 1863.

${ }_{82}$ Ibidem, Leg. 1465. Informe de don Francisco de Aguirre y Álava, 12 de febrero de 1684.

${ }^{83}$ Ibidem, Leg. 1476. Consulta del Consejo de Hacienda en Sala de Millones, 10 de abril de 1684 .

${ }^{84} \mathrm{Ibidem}$, Leg. 1465. Consulta de la Junta de Encabezamiento, 14 de marzo de 1684.
} 
arrendadores, sin que comunicasen esta conveniencia a los lugares, gozando la mayor el arrendador con la baja del arrendamieno, y el vasallo y los pueblos el mismo gravamen de la contribución " ${ }^{85}$.

Si el menoscabo de los ingresos fiscales fue el pretexto esgrimido por los consejeros de Hacienda que defendían el procedimiento anterior de gobierno de las rentas provinciales, la existencia de los superintendentes como responsables máximos de su administración y cobranza provocará asimismo una fuerte réplica del Consejo de Castilla, dispuesto a que asuman dichas funciones los corregidores, con lo que se reducirán costes y se obviarán posibles arbitrariedades que perjudiquen a los súbditos, según el contenido de una consulta del mes de diciembre de 1683 en respuesta a un memorial de quejas de la ciudad de Segovia ${ }^{86}$. El Consejo de Hacienda, por supuesto, rechazará tal sugerencia en enero de 1684 por cuanto que de admitirse quedarian dañadas las rentas provinciales al no poder actuar jurídicamente contra los corregidores en los casos de malversación de fondos públicos o simple negligencia en las cobranzas, por depender su nombramiento del Consejo de Castilla, inconveniente que, sin embargo, será rebatido por este organismo el 9 de mayo con razones nuevas y más convincentes, pues ahora, además de las expuestas, se realza el beneficio que obtendrán los lugares de aunarse en unos mismos individuos el gobierno de la justicia y el de los impuestos, tarea a la que se consagrarán "sujetos de más grado», en otras palabras, mejor preparados y de mayor alcurnia, sin olvidar que está prevenido han de entregar fianzas en el Consejo de Hacienda para garantizar su gestión, quedando incapacitados para ser promovidos a otros empleos mientras no conste en la Cámara de Castilla «haber cumplido con su obligación conforme las determinaciones" de aquel instituto ${ }^{87}$. El peso específico del Consejo de Castilla en las directrices políticas de la Corona y su afinidad de intereses con los diputados de las ciudades con voto en Cortes, que no desean perder su influencia en el negociado del servicio de millones, irá socavando toda oposición, primero, en la Sala de Millones y, luego, en el Consejo de Hacienda, el cual se aviene por fin en agosto de 1684 a delegar en los corregidores la administración de las rentas de aquellas provincias que estuviesen

85 Ibidem, Leg. 1444. Informe de 26 de octubre de 1683.

86 AHN, Conss, Leg. 7195, exp. 66.

${ }_{87}$ Ibidem, Leg. 7128, exp. 27. Consulta del Consejo de Hacienda, 7 de enero de 1684 y consulta del Consejo de Castilla, 9 de mayo de 1684 . 
encabezadas, sin sueldo pero con «una ayuda de costa proporcionada a lo que obraren, que es lo mismo que se ejecutó por lo pasado" ${ }^{88}$.

\section{CONCLUSIONES}

A finales de 1684 se puede afirmar que el contenido del decreto de 1682 había quedado bastante desvirtuado, a lo que contribuirá, a partir de 1686, el retorno al sistema de arriendos, contra el cual se pronunció, en un memorial digno de encomio, el contador de Valladolid, don Pedro Fernández de la Pradilla, cuya sola voz, empero, no logró acallar las interesadas de los arrendatarios y asentistas ni las de los diputados de las ciudades ${ }^{89}$. No obstante, algunos cambios introducidos en el negociado de las rentas provinciales resultaron irreversibles. Así, por ejemplo, éstas no se podrán arrendar en adelante por separado y, cualquiera que fuere la forma en que se administren, su gobierno estará centralizado en las capitales de provincia - los ingresos se efectuarán en las arcas o tesorerías de los partidos conforme a lo prescrito en la Instrucción de 1682-, bajo la autoridad de los corregidores, pues se piensa que dotándoles de competencias jurídicas en asuntos fiscales se impedirán más fácilmente los abusos de las oligarquías urbanas y se propiciarán los expedientes contra los defraudadores o contra quienes usurpan por otros procedimientos las rentas de la Corona, lo cual no se conseguía ejecutar cuando dichas funciones recaían en los administradores nombrados por el Consejo de Hacienda, dadas las injerencias de aquéllos como jueces de primera instancia ante las quejas formuladas por quienes trataban de eludir el pago de los tributos o las confiscaciones previstas por la ley en los casos de contrabando o comercio ilegal de mercancías en las ciudades. La medida, adoptada por la Corona, entrañaba, desde luego, un riesgo mayor en la gestión de las rentas provinciales, por cuanto que los corregidores podían favorecer a las justicias de los concejos para no acarrearse problemas en los juicios de residencia, en los que éstas intervenían activamente con sus testificaciones. De aquí, por tanto, que los partidarios de dotar al Estado de un dominio más amplio en el gobierno

${ }^{88}$ AGS, $C J H$, Leg. 1476. Consulta del Consejo en Sala de Millones, 23 de agosto de 1684. La consulta de la Sala de Millones está fechada el 11 de julio.

89 BL, Egg, 2084, fol. 309-388. 
de los impuestos no cesen en su propósito de que sea el Consejo de Hacienda y no otro tribunal quien designe los ministros que han de estar al frente de la administración de las rentas provinciales, como se infiere del decreto de 1691, en el que nuevamente se instituyen superintendencias con las mismas atribuciones que tenían en 1682, si bien, por lo que se refiere al encabezamiento general del Reino nunca más se volverá a plantear, quizá porque para entonces se buscaban otras alternativas que, sin tanto coste ni esfuerzo para los ministros de Hacienda, consiguieran hacer realidad el objetivo soñado de la época: el alivio fiscal de los pueblos y su renacer económico. 
Absolutismo y fiscalidad en Castilla a fines del siglo xvII...

CUADRO III

RELACIÓN DEL CONTADOR DE LA SUPERINTENDENCIA DE VALLADOLID DE LAS RENTAS PROVINCIALES

\begin{tabular}{|c|c|c|c|c|}
\hline Renta & $\begin{array}{l}\text { Encabezamiento } \\
\text { hasta } 1682 \\
\text { (en mrs) }\end{array}$ & $\begin{array}{l}\text { Encabezamiento } \\
\text { en } 1683 \\
\text { (en } \mathrm{mrs} \text { ) }\end{array}$ & $\begin{array}{c}\text { Rebaja } \\
\text { (en mrs) }\end{array}$ & $\%$ \\
\hline \multicolumn{5}{|l|}{ Alcabalas de Valladolid } \\
\hline $\begin{array}{l}\text { y su infantazgo .......... } \\
\text { Cientos de Valladolid y }\end{array}$ & 11.531 .369 & 11.482 .869 & 48.500 & 0,42 \\
\hline $\begin{array}{l}\text { su infantazgo ............ } \\
\text { Alcabalas de Medina y }\end{array}$ & 22.036 .632 & 18.892 .460 & 3.144 .072 & 14,26 \\
\hline $\begin{array}{l}\text { su partido ................ } \\
\text { Cientos de Medina y su }\end{array}$ & 3.668 .019 & 3.272 .079 & 395.955 & 10,79 \\
\hline $\begin{array}{l}\text { partido } \ldots . . . \ldots . . . . . . . . \\
\text { Alcabalas de Olmedo y }\end{array}$ & 10.831 .986 & 10.806 .534 & 25.452 & 0,23 \\
\hline $\begin{array}{l}\text { su partido } . . . . . . . . . . . . \\
\text { Cientos de Olmedo y su }\end{array}$ & 1.382 .596 & 1.257 .692 & 124.904 & 9.03 \\
\hline $\begin{array}{l}\text { partido } \ldots . . . \ldots \ldots \ldots \\
\text { Alcabalas de Tordesillas }\end{array}$ & 1.117 .404 & 885.076 & 232.328 & 20,7 \\
\hline $\begin{array}{l}\text { y su partido } . . . . . . . . . . \\
\text { Cientos de Tordesillas y }\end{array}$ & 2.266 .081 & 2.266 .081 & - & - \\
\hline $\begin{array}{l}\text { su partido ............... } \\
\text { Alcabalas de Tordehu- }\end{array}$ & 1.759 .156 & 1.516 .000 & 249.156 & 14,6 \\
\hline $\begin{array}{l}\text { mos ....................... } \\
\text { Millones de Valladolid y }\end{array}$ & 424.069 & 424.069 & 一 & - \\
\hline su provincia $\ldots \ldots \ldots \ldots$ & 70.875 .000 & 62.165 .804 & 8.709 .196 & 12,28 \\
\hline $\begin{array}{l}\text { Servicio ordinario y ex- } \\
\text { traordinario de Vallado- } \\
\text { lid, su provincia y tierras } \\
\text { del conde de Benavente }\end{array}$ & & & & \\
\hline$\ldots \ldots \ldots \ldots \ldots \ldots \ldots \ldots$ & 5.318 .348 & 5.318 .348 & - & - \\
\hline Total & 131.210 .555 & 118.028 .992 & 12.929 .563 & 11 \\
\hline
\end{tabular}

Fuente: British Library, Egg, 2.084, fol. 371. 


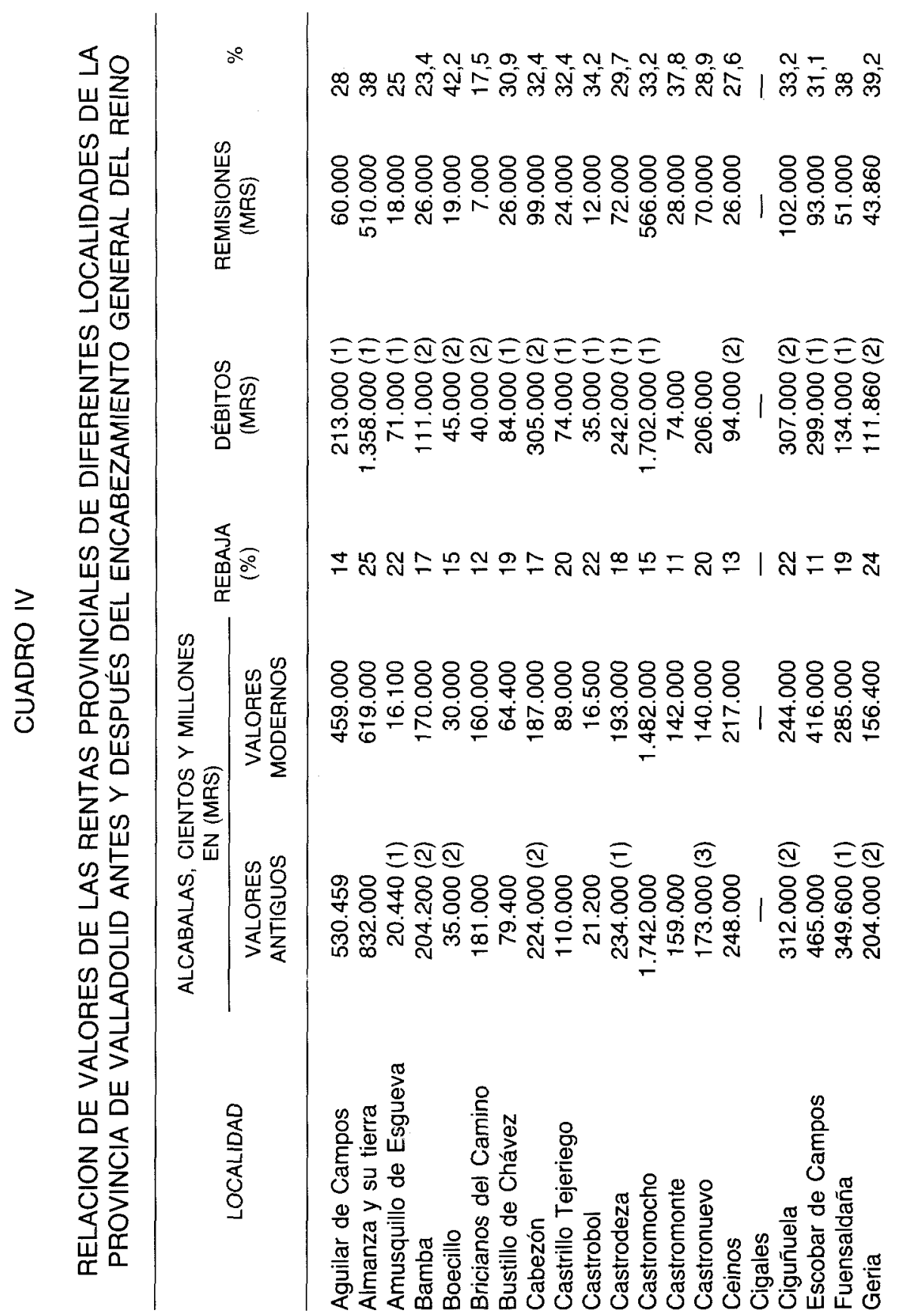




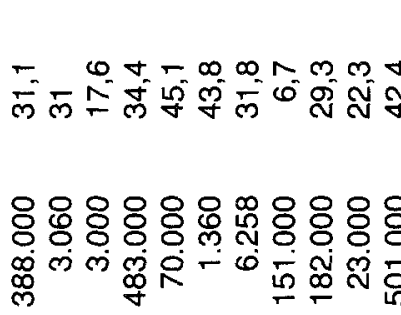

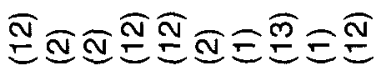
8.8808060808

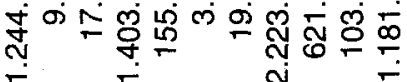

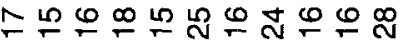

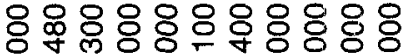

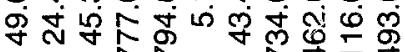

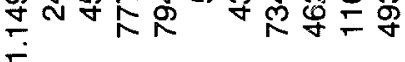

तิ

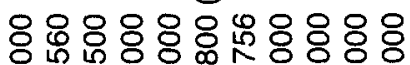

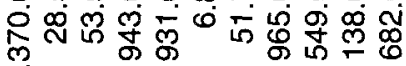

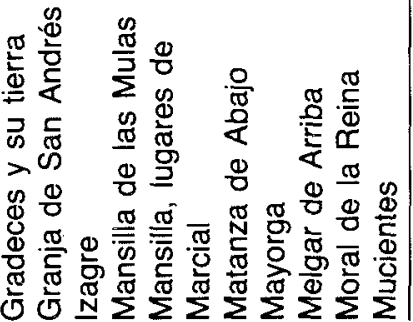

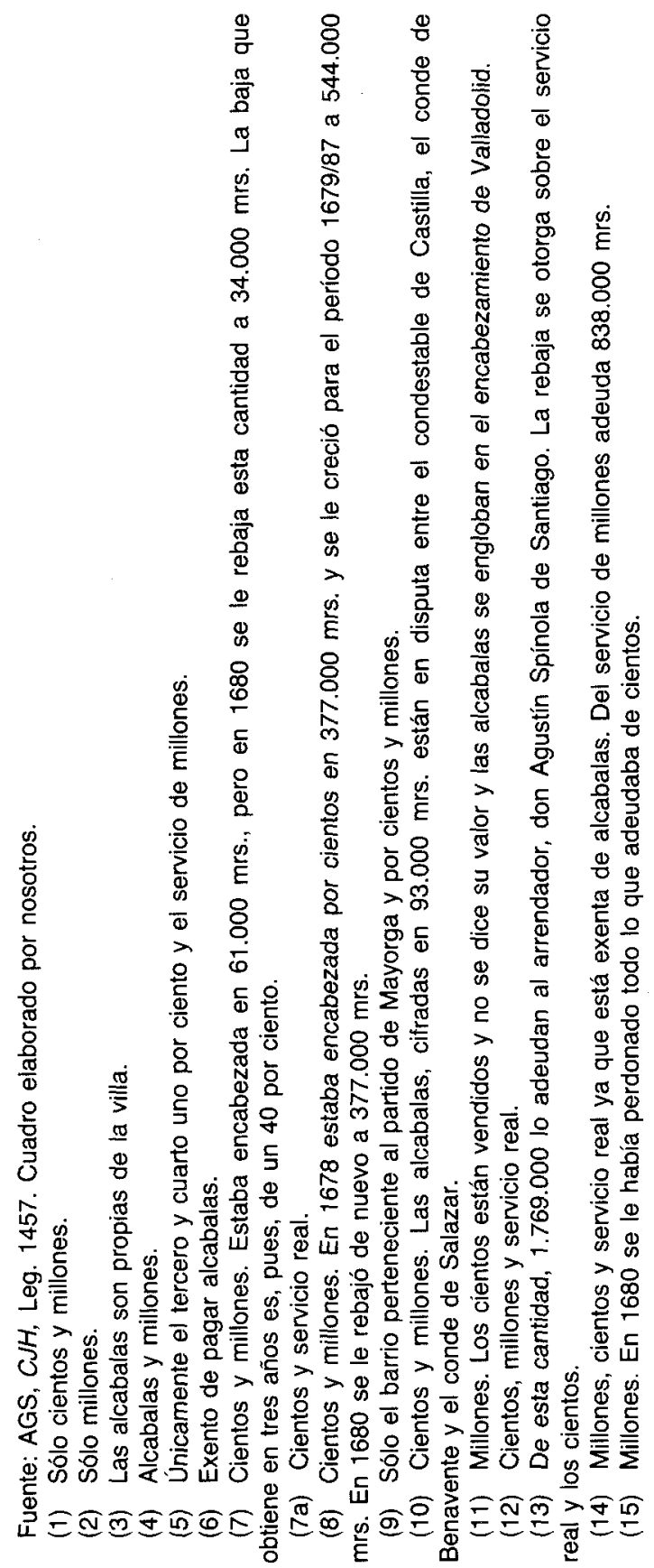




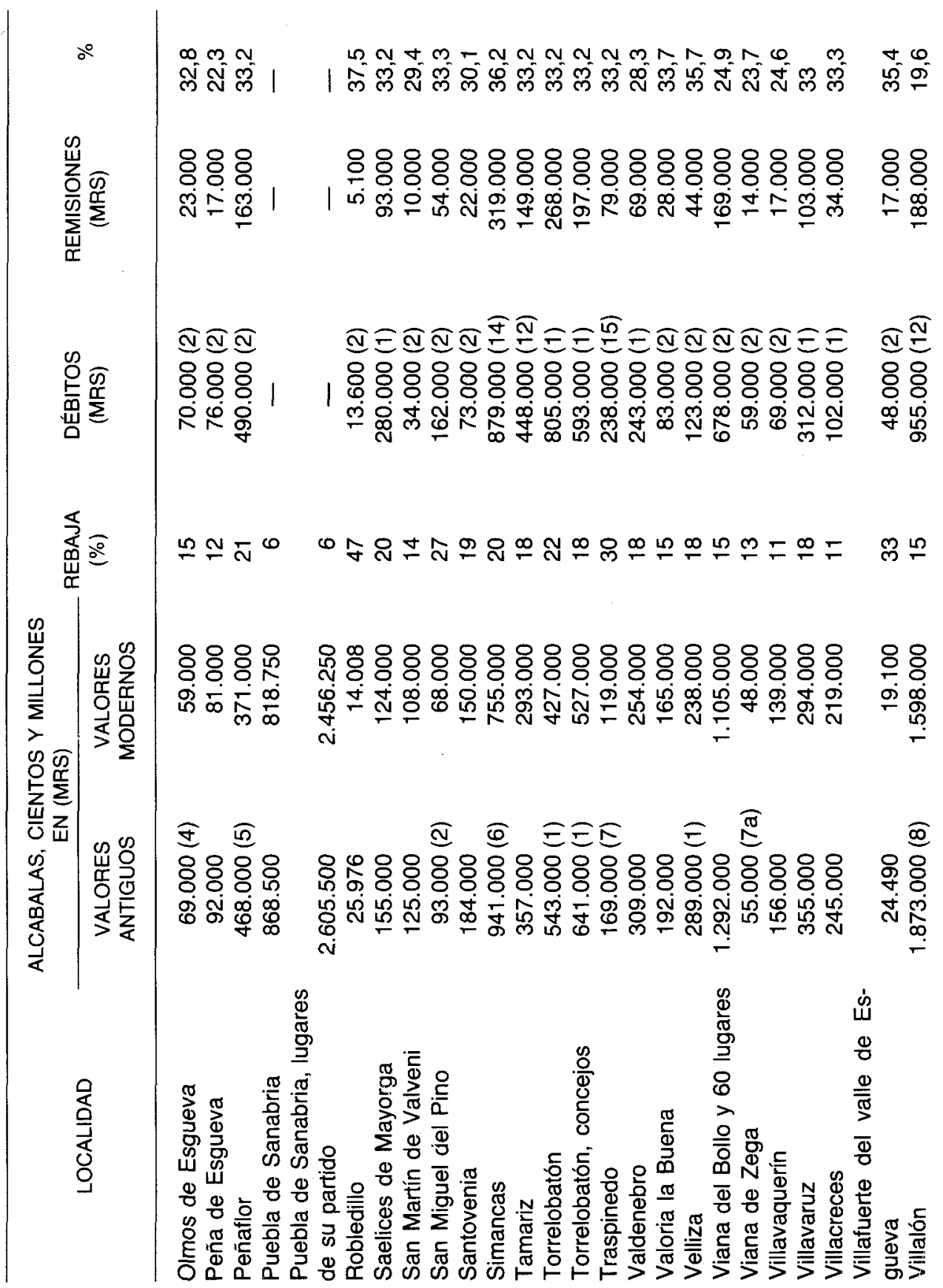




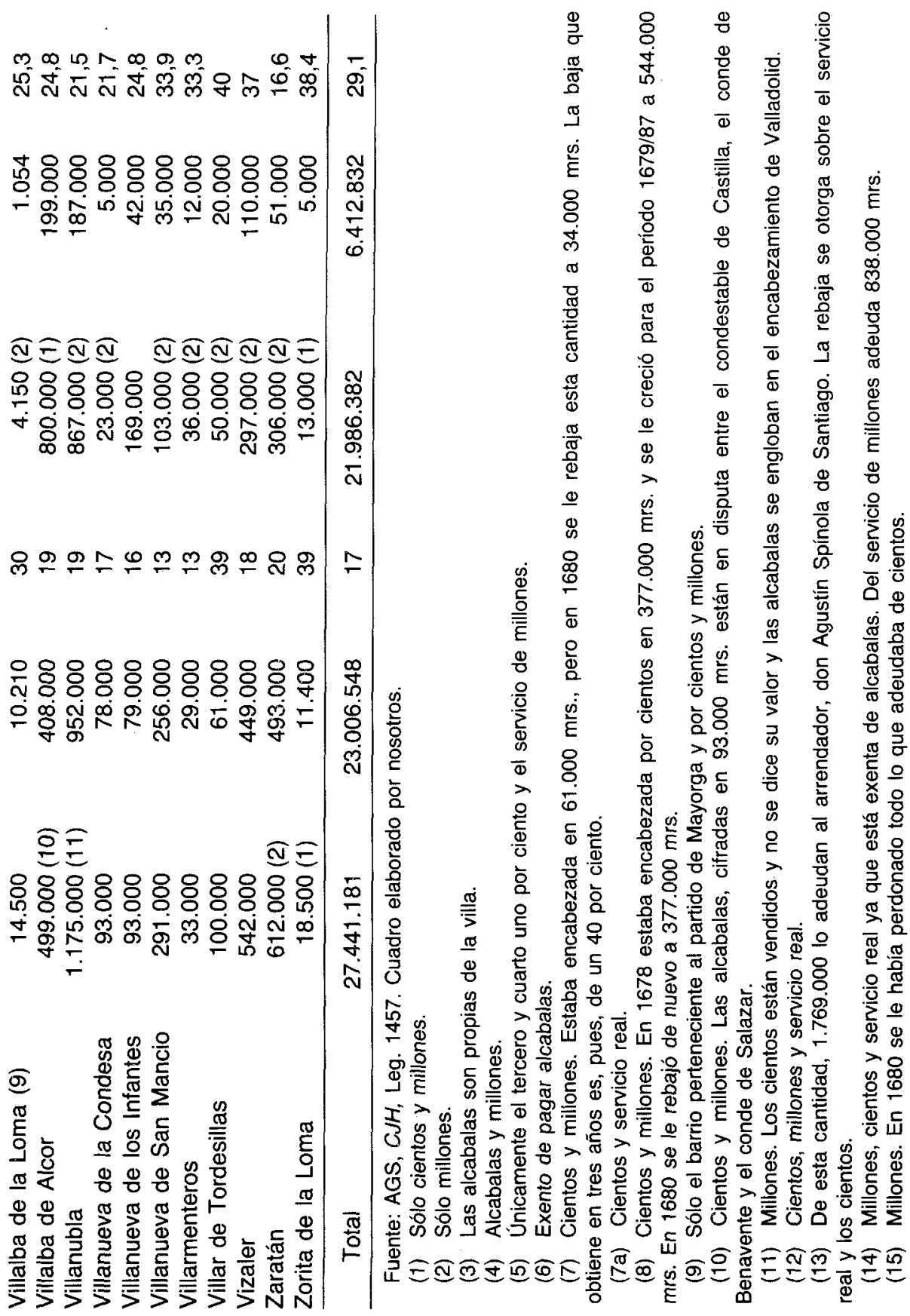




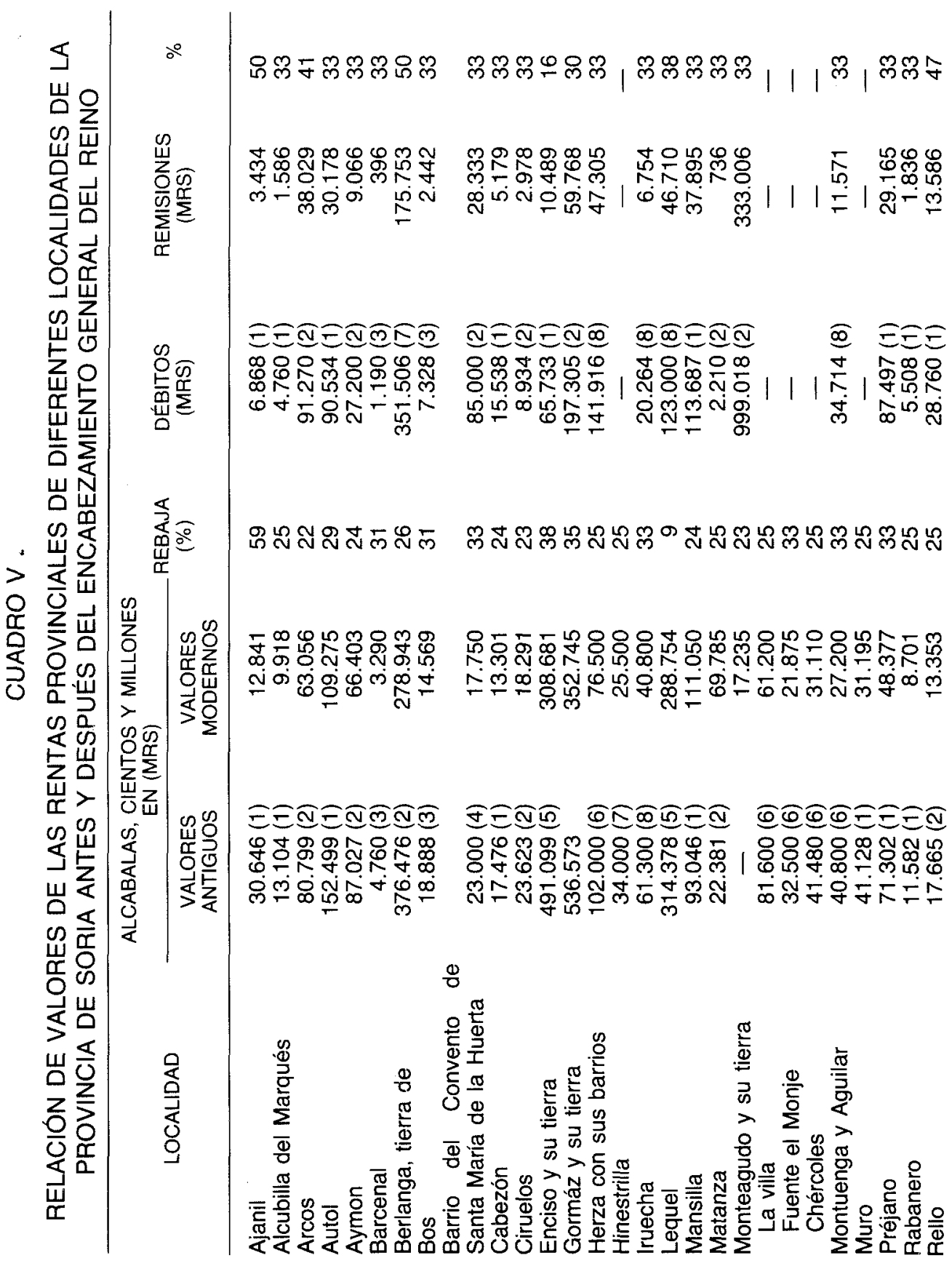




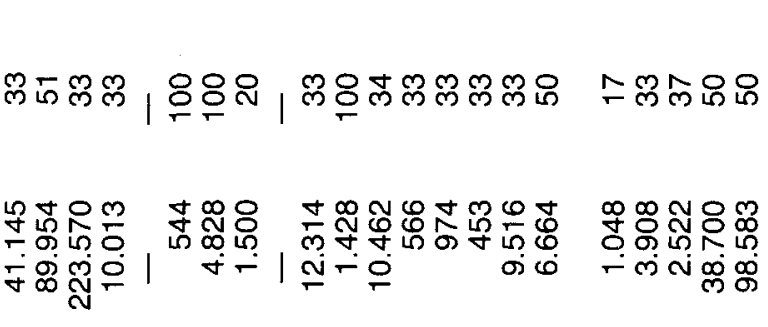

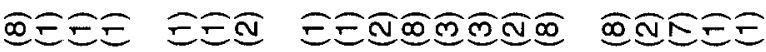

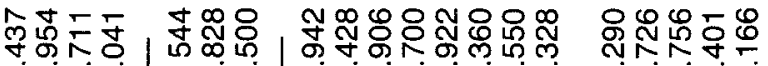

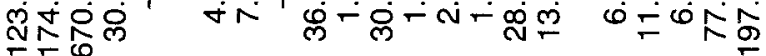
NTt

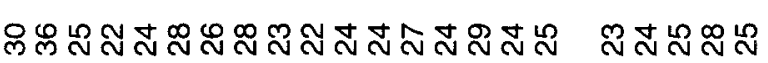

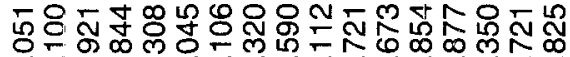
我苠品

冓

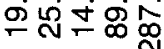

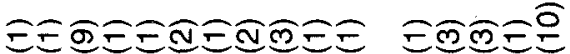

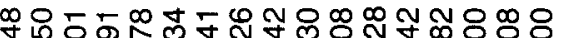

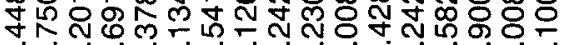

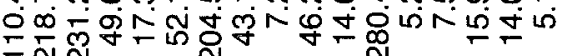
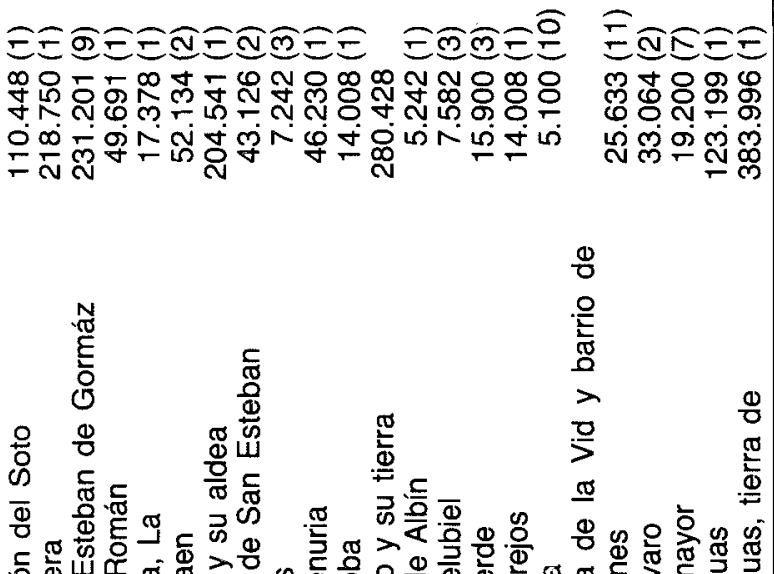

8

은

के

뜬

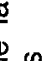

10

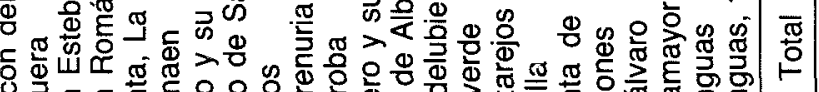

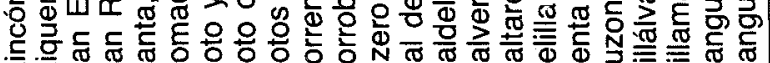

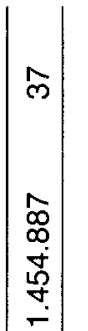

ष

$\frac{\mathscr{d}}{\frac{\mathscr{d}}{\overparen{D}}}$

$\bar{\sigma}$

5

品

$\frac{\dot{\rho}}{\frac{9}{6}}$

$\stackrel{0}{0}$

두

(⿻)

$\frac{\sqrt{8}}{8}$

$\frac{8}{\pi}$ $\frac{0}{0}$

赵

8

के

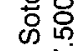

ส

टू क के

离 늠

官要

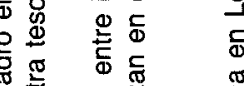

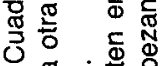

œ

음

> Ф

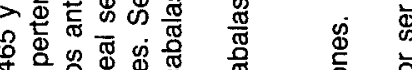

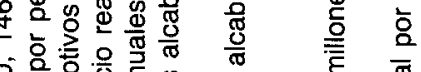

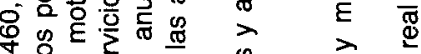

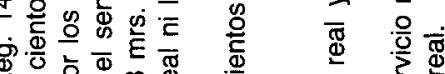

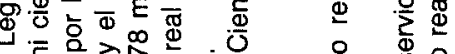

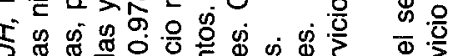

可

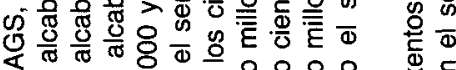

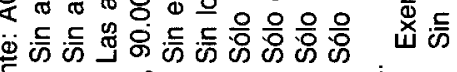

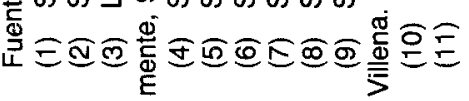

